\title{
Alkylated Benzodithienoquinolizinium Salts as Possible Non-Fullerene Organic N-Type Semiconductors: An Experimental and Theoretical Study
}

\author{
Andrés Aracena ${ }^{1, *}$, Marcos Caroli Rezende $^{2}\left(\mathbb{D}\right.$, Macarena García $^{3}$, Karina Muñoz-Becerra $^{4}(\mathbb{D}$, \\ Kerry Wrighton-Araneda ${ }^{5}$, Cristian Valdebenito ${ }^{6}$, Freddy Celis ${ }^{3}$ and Octavio Vásquez ${ }^{7}$ (i)
}

Citation: Aracena, A.; Rezende, M.C.; García, M.; Muñoz-Becerra, K.; Wrighton-Araneda, K.; Valdebenito, C.; Celis, F.; Vásquez, O. Alkylated Benzodithienoquinolizinium Salts as Possible Non-Fullerene Organic N-Type Semiconductors: An Experimental and Theoretical Study. Materials 2021, 14, 6239. https:// doi.org/10.3390/ma14216239

Academic Editors: Martin Weis and Arunas Ramanavicius

Received: 6 September 2021

Accepted: 14 October 2021

Published: 20 October 2021

Publisher's Note: MDPI stays neutral with regard to jurisdictional claims in published maps and institutional affiliations.

Copyright: (C) 2021 by the authors Licensee MDPI, Basel, Switzerland. This article is an open access article distributed under the terms and conditions of the Creative Commons Attribution (CC BY) license (https:// creativecommons.org/licenses/by/ $4.0 /)$.
1 Instituto de Ciencias Naturales, Universidad de las Américas, Manuel Montt 948, Santiago 7500000, Chile

2 Facultad de Química y Biología, Universidad de Santiago de Chile, Santiago 9160000, Chile; marcos.caroli@usach.cl

3 Laboratorio de Procesos Fotónicos y Electroquímicos, Facultad de Ciencias Naturales y Exactas, Universidad de Playa Ancha, Valparaíso 2340000, Chile; macarena.garcia@upla.cl (M.G.); freddy.celis@upla.cl (F.C.)

4 Dirección de Investigación y Postgrado, Universidad de Aconcagua, Pedro de Villagra 2265, Santiago 7630000, Chile; karina.munoz@uac.cl

5 Programa Institucional de Fomento a la Investigación, Desarrollo e Innovación, Universidad Tecnológica Metropolitana, Ignacio Valdivieso 2409, Santiago 8940577, Chile; Kerry.wrighton@utem.cl

6 Centro Integrativo de Química y Biología Aplicada (CIBQA), Facultad de Ciencias de la Salud, Universidad Bernardo O'Higgins, Santiago 8320000, Chile; cristian.valdebenito@usach.cl

7 Facultad de Ciencias Físicas y Matemáticas, Universidad de Chile, Santiago 8320000, Chile; svasqueza@ing.uchile.cl

* Correspondence: aaracena@udla.cl

\begin{abstract}
Three photobicyclized benzodithienoquinolizinium tetrafluoroborates (BPDTQBF4) were prepared and evaluated by UV-Vis and fluorescence spectral, electrochemical analysis, and by theoretical calculations as possible organic n-type semiconductors. Evaluation and comparison of their LUMO levels, HOMO-LUMO energy gaps as monomeric and $\pi$-stacked dimers with those of other materials, suggest their potential as organic n-type semiconductors. Calculations of their relative charge carrier mobilities confirmed this potential for one derivative with a long (C-14) alkyl chain appended to the polycyclic planar $\pi$-system.
\end{abstract}

Keywords: benzodithienoquinolizinium cations; photocyclization of $\mathrm{N}$-aryl pyridinium salts; $\pi$-stacked assemblies; organic semiconductors

\section{Introduction}

The development of new and more efficient organic semiconductors is an active area of research with a plethora of applications. They are normally classified as p-type (electrondonating or hole-conducting), n-type (electron-accepting or electron-conducting), and ambipolar (hole- and electron-conducting) semiconductors. The preparation and the study of electron-donating or p-type semiconductors have received considerable attention [1]. Compared to them, the development of their n-type counterparts has been left behind due in part to their greater atmospheric sensitivity and the rather limited number of molecular scaffolds employed for their synthesis. Research has been mainly concentrated on fullerene derivatives because of their high electron affinity and electron mobility [2-6]. Due to their ease of polymer intercalation and efficient electron transport, fullerene derivatives became an important class of electron acceptors for highly efficient organic solar cells, particularly when coupled with high-performance, electron-donating polymers [7]. Table 1 shows a comparison of some properties of fullerene derivatives and small molecules, when they are used as n-type semiconductors in organic solar cells. 
Table 1. LUMO energy levels (obtained by electrochemical measurements), electron mobility values, donor/acceptor ratio and power conversion efficiency (PCE\%) of fullerene derivatives and some organic small molecules used as n-type semiconductors.

\begin{tabular}{ccccc}
\hline Acceptor. & LUMO Energy (eV) & $\begin{array}{c}\boldsymbol{\mu}_{\mathbf{e}} \\
\left(\mathbf{c m}^{\mathbf{2}} \cdot \mathbf{V}^{-\mathbf{1}} \cdot \mathbf{s}^{-\mathbf{1}}\right)\end{array}$ & D/A Ratio & PCE (\%) \\
\hline PC 61 BM [8] & -3.70 & $2.39 \times 10^{-4}$ & $1: 0.7$ & 3.80 \\
$\mathrm{NC}_{61}$ BM [8] & -3.68 & $2.27 \times 10^{-4}$ & $1: 0.7$ & 4.09 \\
$\mathrm{AC}_{61}$ BM [8] & -3.75 & $1.75 \times 10^{-4}$ & $1: 0.7$ & 1.14 \\
PyC61BM [8] & -3.72 & $2.13 \times 10^{-4}$ & $1: 0.7$ & 1.95 \\
oo-PDI [9] & -3.90 & - & $1: 1$ & 8.12 \\
PDI-3 [10] & -3.63 & - & $1: 2$ & 0.96 \\
PDI-1 [10] & -3.67 & - & $1: 2$ & 0.13 \\
NDITz [11] & -3.99 & 0.15 & - & - \\
NDINI [12] & -4.20 & 1.75 & - & - \\
C8-NDTI [13] & -4.00 & 0.05 & - & - \\
\hline
\end{tabular}

Despite these advantages, however, recent studies have suggested that degradation of organic solar cells may be due to their high photo- and oxygen-sensitivity, and their tendency to form macroscopic aggregates [14-16]. Fullerene and its derivatives are weak absorbers of visible light $[17,18]$. This feature results in poor light-harvesting properties, thereby substantially reducing the potential of the photocurrent generation of organic solar cells in the UV-Visible range of the solar spectrum. These limitations and the poor synthetic flexibility shown by fullerene have led to efforts to develop other organic n-type semiconductors with a non-fullerene scaffold. Research in this field has concentrated on various oligomers $[19,20]$ and polymeric materials $[21,22]$, with few examples of small molecules.

A variety of oligomeric $N$-hydrogenated/ $N$-methylated pyridinium salts have been used as cathode interfacial layers to increase the electron-mobility without modifying the work function of the electrode [23,24]. Oligothiophenes [25-27] have exhibited decreased LUMO energies, together with increased electron mobilities. Many of these properties can be anticipated theoretically, allowing for the identification of potentially interesting materials for the development of n-type organic semiconductors. An example of such computational studies is the theoretical calculation of HOMO-LUMO energy gaps of thiophenebased discotic systems, their charge-transfer rates, and relative charge-mobilities [28-31]. Theoretical structural and electronic properties of these kinds of compounds have been studied [32-35]. A series of ten 2-naphthyl and 2-anthrylbithiophene derivatives were synthesized and studied as possible n-type semiconductors [36]. Spectroscopic measurements and X-ray analyses were carried, together with theoretical calculations with DFT methods. Some experimental properties were in good agreement with the theoretical predictions. Theoretical and experimental studies with monomeric and dimeric DAE molecules have been carried out [37]. Theoretical calculations showed that the $\pi$ extension of the dimer produced a decrease in the LUMO energy by comparison with the monomer. Low values for the internal reorganization energies $(\lambda)$ were obtained for the dimer when compared with the monomer, leading to a higher semiconductor performance of the former.

Polycyclic aromatic hydrocarbons (PAHs) have been proposed as semiconductors due to their ability to produce a discotic stacking, allowing an efficient charge-transport through their vertical intermolecular axis [38-40]. Polycyclic pyridinium salts are positively charged PAHs $[41,42]$ and they constitute a class of electron-deficient planar $\pi$ system whose versatile synthesis can include other electron-donor or acceptor groups. Recently, pyridinium-based molecules have been used in dye-sensitized solar cells $[43,44]$. A pyridinium fragment, appended to a polyelectrolyte system, enabled efficient electron transport/collection, giving rise to a PCE value of $16.14 \%$ in an organic solar cell [45].

The above features of pyridinium- and thiophene-based extended $\pi$-systems and their possible formation of a discotic stacking have attracted our attention as a new class of electron-deficient systems with potential use in solar cells. To the best of our knowledge, 
photocyclized pyridinium salts have never been proposed as potential n-type organic semiconductors. Their synthesis by photocyclization of readily obtained $N$-arylpyridinium salts has been described for more than thirty years [46,47]. More recently, some of their derivatives such as 2-phenyl-benzo[8,9]quinolizino[4,5,6,7-fed]-phenanthridinylium tetrafluoroborate $\left(\mathrm{PQPBF}_{4}\right)$ have been shown to form columnar $\pi$-stacked aggregates in the solid phase [48]. Although such aggregation in acetonitrile has been disputed [49], spectral evidence for its formation in water has been obtained in our laboratories [50]. Thus, planar electron-deficient $\pi$-systems like $\mathrm{PQP}^{+}$or its dithienoquinolizium analog $\mathrm{BPDTQ}^{+}$should be good candidates for promising n-type semiconductors. The incorporation of side-chains of variable size into $\mathrm{PQP}^{+}$derivatives has led to materials with different discotic stackings in the solid state [51,52], suggesting their use in supramolecular assemblies on electronic surfaces $[53,54]$.

In line with other theoretical studies [55] that not only shed light on their properties, but also help identify new interesting compounds by comparing their properties with those of known materials, we investigate in the present communication the properties of polycyclic pyridinium salts as candidates for the development of n-type organic semiconductors. Besides their electron-deficient character and their potential ability to form columnar aggregates, other structural features were included in their synthesis, which were above-mentioned as leading to better n-type organic semiconductors. They include the presence of dithieno substituents to the pyridinium core, and of alkyl sidechains of variable size, all of which should be expected to improve the charge-mobility in these systems. The effect of these structural modifications on a discotic arrangement of these molecules was assessed by calculations of their electronic behavior, injection, and charge-transport properties, HOMO and LUMO energies, and supported by experimental determination of their thermal stability and oxidation/reduction potentials through electrochemical measurements.

\section{Materials and Methods}

\subsection{Synthesis of Polycyclic Heteroaromatic Salts}

Melting points were measured with a capillary Microthermal apparatus and were not corrected. ${ }^{1} \mathrm{H}$ NMR spectra were obtained with a Bruker Avance $400 \mathrm{MHz}$ and the samples were prepared in acetone- $\mathrm{d}_{6}$. The UV-Vis spectra were recorded with a Cary 50 spectrometer. Fluorescence spectra were recorded with a Perkin Elmer LS55 spectrofluorimeter.

The precursor 2,6-bis(2-thienyl)-4-phenylpyrylium tetrafluoroborate (2) was prepared following a reported procedure by condensation of benzaldehyde and 1-phenyl-3-(2thienyl)propenone (1) in the presence of the diethyl ether-boron trifluoride adduct [56].

The preparation of the $N$-(4-alkylphenyl)-2,6-bis(2-thienyl)-4-phenylpyridinium tetrafluoroborate $(\mathbf{3 a}-\mathbf{c})$ followed a general procedure by refluxing for $12 \mathrm{~h}$ in ethanol $(30 \mathrm{~mL})$ equimolar amounts of the precursor (2) and 4-alkylaniline $(0.37 \mathrm{mmol})$, filtering the resulting precipitate, washing with cold ethanol, and recrystallizing from ethanol to give the corresponding fluoroborates $(\mathbf{3 a}-\mathbf{c})$. In this way, the following fluoroborate salts were prepared:

$\mathrm{N}$-(4-Hexylphenyl)-4-phenyl-2,6-bis(2-thienyl)pyridinium tetrafluoroborate (3a), yield 70\%, mp $126-129^{\circ} \mathrm{C} .{ }^{1} \mathrm{H}$ NMR $\left(400 \mathrm{MHz}\right.$, Acetone- $\left.\mathrm{d}_{6}\right) \delta 8.71(\mathrm{~s}, 2 \mathrm{H}), 8.30(\mathrm{~d}, \mathrm{~J}=7.2 \mathrm{~Hz}$, 2H), $7.87(\mathrm{~d}, \mathrm{~J}=4.9 \mathrm{~Hz}, 2 \mathrm{H}), 7.80-7.63(\mathrm{~m}, 7 \mathrm{H}), 7.43(\mathrm{~d}, \mathrm{~J}=8.1 \mathrm{~Hz}, 2 \mathrm{H}), 7.17(\mathrm{t}, \mathrm{J}=4.3 \mathrm{~Hz}$, $2 \mathrm{H}), 2.86-2.68(\mathrm{~m}, 4 \mathrm{H}), 1.77-1.57(\mathrm{~m}, 2 \mathrm{H}), 1.32(\mathrm{~s}, 4 \mathrm{H}), 0.91(\mathrm{t}, \mathrm{J}=6.0 \mathrm{~Hz}, 3 \mathrm{H})$.

$\mathrm{N}$-(4-Decylphenyl)-4-phenyl-2,6-bis(2-thienyl)pyridinium tetrafluoroborate (3b), yield $73 \%$, mp $123-125^{\circ} \mathrm{C} .{ }^{1} \mathrm{H}$ NMR $\left(400 \mathrm{MHz}\right.$, Acetone- $\left.\mathrm{d}_{6}\right) \delta 8.71(\mathrm{~s}, 2 \mathrm{H}), 8.30(\mathrm{~d}, \mathrm{~J}=7.3 \mathrm{~Hz}$, $2 \mathrm{H}), 7.87(\mathrm{~d}, \mathrm{~J}=5.0 \mathrm{~Hz}, 2 \mathrm{H}), 7.80-7.64(\mathrm{~m}, 7 \mathrm{H}), 7.43(\mathrm{~d}, \mathrm{~J}=8.0 \mathrm{~Hz}, 2 \mathrm{H}), 7.17(\mathrm{t}, \mathrm{J}=4.3 \mathrm{~Hz}$, $2 \mathrm{H}), 2.86-2.69(\mathrm{~m}, 4 \mathrm{H}), 1.73-1.60(\mathrm{~m}, 2 \mathrm{H}), 1.32(\mathrm{~s}, 12 \mathrm{H}), 0.91(\mathrm{t}, \mathrm{J}=6.3 \mathrm{~Hz}, 3 \mathrm{H})$.

$\mathrm{N}$-(4-Tetradecylphenyl)-4-phenyl-2,6-bis(2-thienyl)pyridinium tetrafluoroborate (3c), yield $64 \%, 122-124{ }^{\circ} \mathrm{C} .{ }^{1} \mathrm{H}$ NMR $\left(400 \mathrm{MHz}\right.$, Acetone- $\left.\mathrm{d}_{6}\right) \delta 8.71(\mathrm{~s}, 2 \mathrm{H}), 8.30(\mathrm{~d}, \mathrm{~J}=7.3 \mathrm{~Hz}$, 2H), $7.87(\mathrm{~d}, \mathrm{~J}=5.0 \mathrm{~Hz}, 2 \mathrm{H}), 7.78-7.63(\mathrm{~m}, 7 \mathrm{H}), 7.43(\mathrm{~d}, \mathrm{~J}=8.1 \mathrm{~Hz}, 2 \mathrm{H}), 7.17(\mathrm{t}, \mathrm{J}=4.4 \mathrm{~Hz}$, $2 \mathrm{H}), 2.84-2.64(\mathrm{~m}, 4 \mathrm{H}), 1.72-1.60(\mathrm{~m}, 2 \mathrm{H}), 1.32(\mathrm{~s}, 20 \mathrm{H}), 0.89(\mathrm{t}, \mathrm{J}=6.4 \mathrm{~Hz}, 3 \mathrm{H})$. 
The cyclized 2-phenyl-7-alkyl benzo[ij]pyrido[2,1,6-de]dithieno[3,2-b:2', $3^{\prime}$-g]quinolizinium tetrafluoroborate salts $(\mathbf{4} \mathbf{a}-\mathbf{c})$ were prepared following a general procedure. A solution of the precursor $3 \mathbf{a}-\mathbf{c}(0.5 \mathrm{mmol})$ in $50 \mathrm{~mL}$ of a $1: 5 \mathrm{v} / \mathrm{v}$ mixture of ethanol:hexane was irradiated for $80 \mathrm{~h}$ in a quartz flask in a Rayonet NORPR-100 photochemical reactor with four $300 \mathrm{~nm}$ lamps. The precipitated quinolizinium tetrafluoroborate $4 \mathbf{a}-\mathbf{c}$ was filtered and recrystallized in ethanol. In this way, the following tetrafluoroborate salts $(4 \mathbf{a}-\mathbf{c})$ were prepared:

7-Hexyl-2-phenylbenzo[ij]pyrido[2,1,6-de]dithieno[3,2-b:2', $3^{\prime}$-g]quinolizinium tetrafluoroborate (Hexyl BPDTQBF4) (4a), yield 33\%, mp $275{ }^{\circ} \mathrm{C}$ (dec.). ${ }^{1} \mathrm{H}$ NMR $(400 \mathrm{MHz}$, Acetone-d6) $\delta 9.05(\mathrm{~s}, 2 \mathrm{H}), 8.92(\mathrm{~s}, 2 \mathrm{H}), 8.62(\mathrm{~d}, \mathrm{~J}=5.21 \mathrm{~Hz}, 2 \mathrm{H}), 8.58(\mathrm{~d}, \mathrm{~J}=5.26 \mathrm{~Hz}$, $2 \mathrm{H}), 8.42-8.35(\mathrm{~m}, 2 \mathrm{H}), 7.77(\mathrm{~d}, \mathrm{~J}=5.21 \mathrm{~Hz}, 3 \mathrm{H}), 2.86-2.68(\mathrm{~m}, 4 \mathrm{H}), 1.77-1.57(\mathrm{~m}, 2 \mathrm{H}), 1.32$ $(\mathrm{s}, 4 \mathrm{H}), 0.91(\mathrm{t}, \mathrm{J}=6.0 \mathrm{~Hz}, 3 \mathrm{H})$.

7-Decyl-2-phenylbenzo[ij]pyrido[2,1,6-de]dithieno[3,2-b:2', $3^{\prime}$-g]quinolizinium tetrafluoroborate (Decyl BPDTQBF4) (4b), yield $38 \%, \mathrm{mp} 240{ }^{\circ} \mathrm{C}$ (dec). ${ }^{1} \mathrm{H}$ NMR (400 MHz, Acetone-d6) $\delta 9.07(\mathrm{~s}, 2 \mathrm{H}), 8.94(\mathrm{~s}, 2 \mathrm{H}), 8.67-8.55(\mathrm{~m}, 4 \mathrm{H}), 8.39$ (d, J = 6.36 Hz, $2 \mathrm{H}), 7.77(\mathrm{~d}, \mathrm{~J}=5.31 \mathrm{~Hz}, 3 \mathrm{H}), 2.86-2.69(\mathrm{~m}, 4 \mathrm{H}), 1.73-1.60(\mathrm{~m}, 2 \mathrm{H}), 1.32(\mathrm{~s}, 12 \mathrm{H}), 0.91$ $(\mathrm{t}, \mathrm{J}=6.3 \mathrm{~Hz}, 3 \mathrm{H})$.

7-Tetradecyl-2-phenylbenzo[ij]pyrido[2,1,6-de]dithieno[3,2-b:2', $3^{\prime}$-g]quinolizinium tetrafluoroborate (Tetradecyl BPDTQBF4) (4c), yield $44 \%$, mp $225{ }^{\circ} \mathrm{C}$ (dec). $1 \mathrm{H}$ NMR (400 MHz, Acetone-d6) $\delta 9.07$ (s, 2H), 8.95 (s, 2H), 8.62 (q, J = $5.40 \mathrm{~Hz}, 4 \mathrm{H}), 8.38$ (d, $\mathrm{J}=6.00 \mathrm{~Hz}, 2 \mathrm{H}), 7.77(\mathrm{~d}, \mathrm{~J}=5.31 \mathrm{~Hz}, 3 \mathrm{H}), 2.84-2.64(\mathrm{~m}, 4 \mathrm{H}), 1.72-1.60(\mathrm{~m}, 2 \mathrm{H}), 1.32(\mathrm{~s}, 20 \mathrm{H})$, $0.89(\mathrm{t}, \mathrm{J}=6.4 \mathrm{~Hz}, 3 \mathrm{H})$.

\subsection{Electrochemical Measurements}

Cyclic voltammetry experiments were carried out in a PalmSens 4 potentiostat/galvanostat/ impedance analyzer, using a one-compartment cell with a conventional three-electrode arrangement. As the working electrode, a glassy carbon electrode ( $\mathrm{CH}$ Instruments, TX, USA) was used; as a counter electrode, we used a Pt wire ( $\mathrm{CH}$ Instruments, TX, USA) and as a reference, we used a $\mathrm{Ag} / \mathrm{AgCl}(3 \mathrm{M} \mathrm{KCl})$ electrode. This last electrode was sealed and separated using a glass tube connected to the solution through a platinum bridge, working as a Lugging capillary. This arrangement avoids any moisture contamination to the working solution at the timescale of the CV experiments [57]. Tetrabutylammonium perchlorate (TBPA) $0.1 \mathrm{M}$ was employed as the supporting electrolyte in $1 \mathrm{mM}$ solutions of the tetrafluoroborate salts in DMF, with scan rates of $100 \mathrm{mV} / \mathrm{s}$.

\subsection{Thermogravimetric Measurements}

The thermogravimetric analysis was performed using a NETZSCH TG 209 F1 Libra thermoanalyzer at a constant heating rate of $3 \mathrm{~K} / \mathrm{min}$ in a range of $30-500{ }^{\circ} \mathrm{C}$. A constant purging gas flow of $20 \mathrm{~mL} / \mathrm{min}$ nitrogen was applied with a protective gas flow of $8 \mathrm{~mL} / \mathrm{min}$ nitrogen. Data analysis was carried out with Proteus Software (version 6.1).

\subsection{Computational Details}

The optimized structures of the monomeric BPDTQ cations and of their tetrafluoroborate salts, and the various conformations of their dimers (parallel and face to face) were calculated with Gaussian 09 [58] employing the hybrid DFT-B3LYP and M062X functionals, with the 6-31G (d) basis set. The electronic spectra of monomeric and dimeric molecules in methanol were obtained by TD-DFT methods with the 6-31G (d) basis set. Solvent effects were mimicked with the polarized continuum model (PCM). Intermolecular non-covalent interactions within the various conformations of the dicationic dimers were depicted with the NCIPLOT software (version 3.0) [59].

Intermolecular orbital overlap for holes and electrons were calculated using the Koopman approximation. 


\section{Results}

3.1. Synthesis of the Polycyclic Heteroaromatic Salts $\mathbf{4 a - c}$

The synthetic route to the heteroaromatic salts $4 \mathbf{a}-\mathbf{c}$ is shown in Scheme 1.

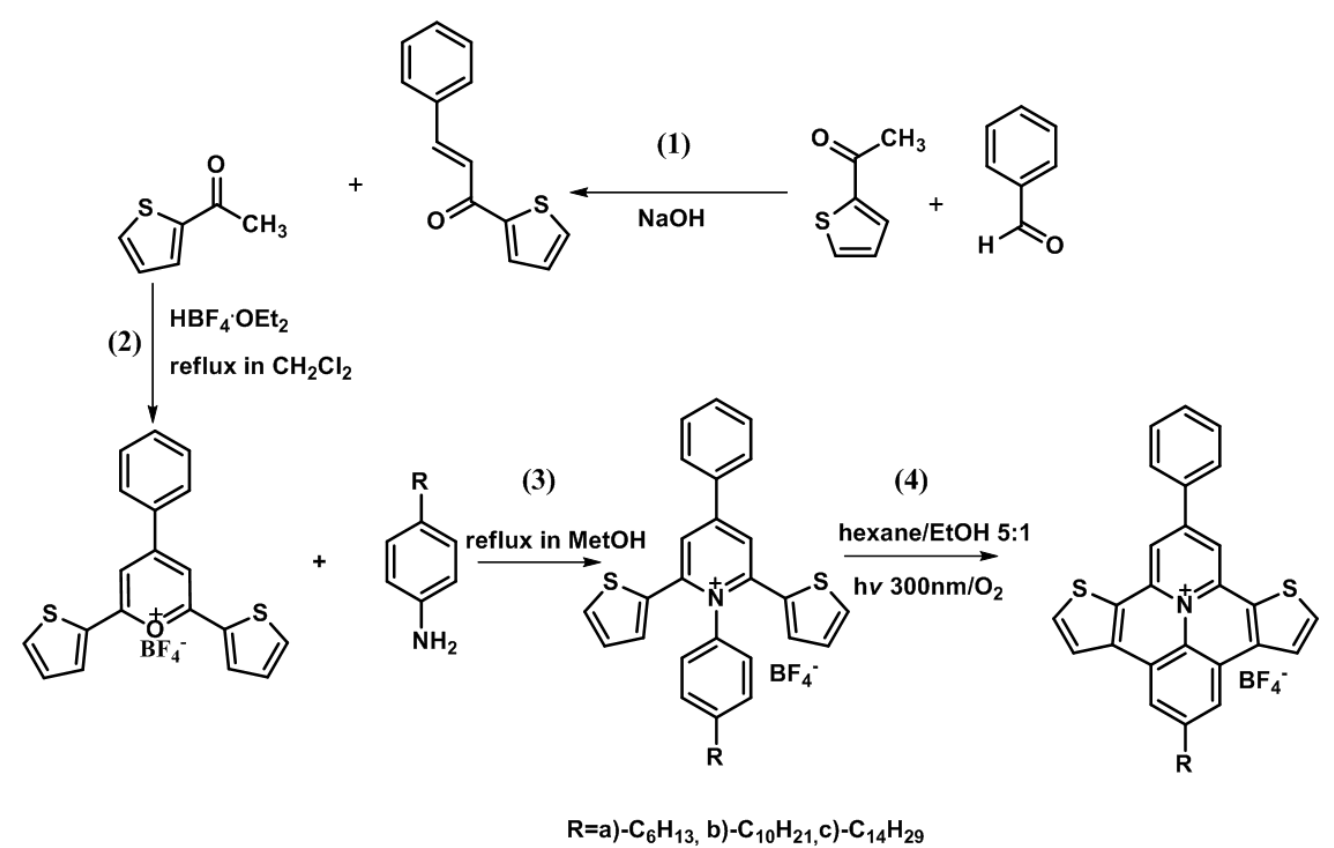

Scheme 1. Synthetic route for the preparation of polycyclic heteroaromatic tetrafluoroborates $4 a-c$.

The basic condensation of 2-thienylethanone with benzaldehyde to form propenone (1), followed by acid-catalyzed cyclization of this product with benzaldehyde to give the pyrylium tetrafluoroborate (2), are classical procedures reported previously [56]. Conversion of (2) into the corresponding $N$-aryl-2,6-bis(2-thienyl)-4-phenyl pyrydinium tetrafluoroborates $3 \mathbf{a}-\mathbf{c}$ by reaction with 4 -alkylanilines also followed a standard procedure, described in the literature [46]. The photocatalytic bicyclization of $\mathrm{N}$-aryl-2,4,6-trisubstituted pyridinium salts has been previously described [47] and the procedure was adapted to the preparation of tetrafluoroborate salts $\mathbf{4 a - c}$ from the corresponding pyridinium salts $3 \mathbf{a}-\mathbf{c}$.

\subsection{Spectroscopic Characterization of Tetrasubtituted and Photocyclized Pyridinium Salts}

The tetrasubtituted pyridinium salts $\mathbf{3 a - c}$ showed two absorption maxima 327 and $312 \mathrm{~nm}$, respectively, in chloroform (Figure 1). When the absorption spectra of these salts were measured in methanol as the solvent, two absorption maxima were also registered at 378 and $385 \mathrm{~nm}$ (7S). The spectra were not affected by the size of the alkyl substituent of the $N$-phenyl group, but there existed a hypsochromic shift of the maxima passing from the chloroform to methanol medium $(-15$ and $-7 \mathrm{~nm})$, probably because of the major stabilization of the ground state of the molecules with the polar protic solvent.

The optical band gap (Eg) for compounds $4 \mathbf{a}-\mathbf{c}$ compounds could be estimated by the equation

$$
\mathrm{E}_{\mathrm{g}}=1241 / \lambda_{\text {onset }}
$$

where $\lambda_{\text {onset }}$ is the low-energy absorption edge obtained from the UV-Visible spectra in chloroform (Figure 2a) employing a geometric method [60]. From $\lambda_{\text {onset }}$ values of 476, 475, and $477 \mathrm{~nm}$ for compounds $4 \mathbf{a}, 4 \mathbf{b}$, and $4 \mathbf{c}$, respectively, $E_{\mathrm{g}}$ values of $2.61,2.60$, and $2.60 \mathrm{eV}$ were obtained. 


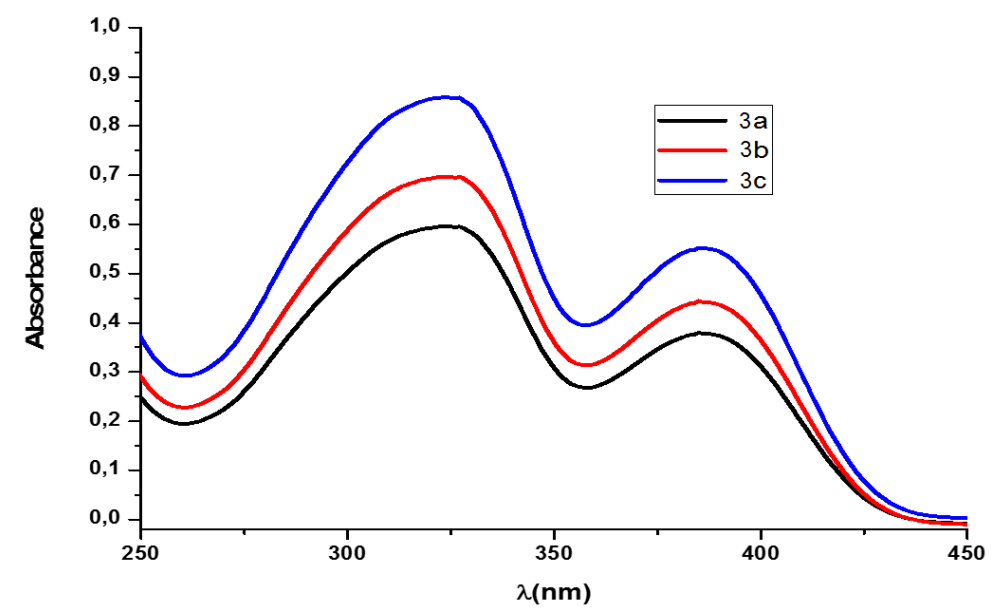

Figure 1. UV-Vis spectra of pyridinium tetrafluoroborates $3 \mathrm{a}-\mathrm{c}$ in chloroform $\left(c a .9 \times 10^{-4} \mathrm{M}\right)$.

Upon cyclization, the extended heterocyclic $\pi$-system exhibited several new bands around 360, 430, and $470 \mathrm{~nm}$, in addition to the major absorption around $330 \mathrm{~nm}$, which consisted of at least two resolved bands (Figure 2).

(a)

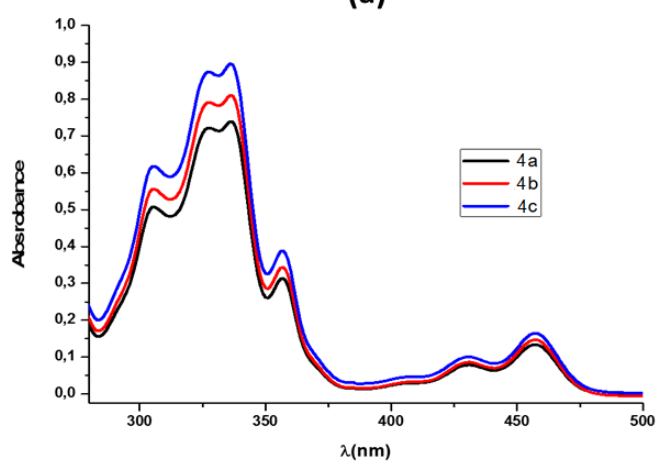

(b)

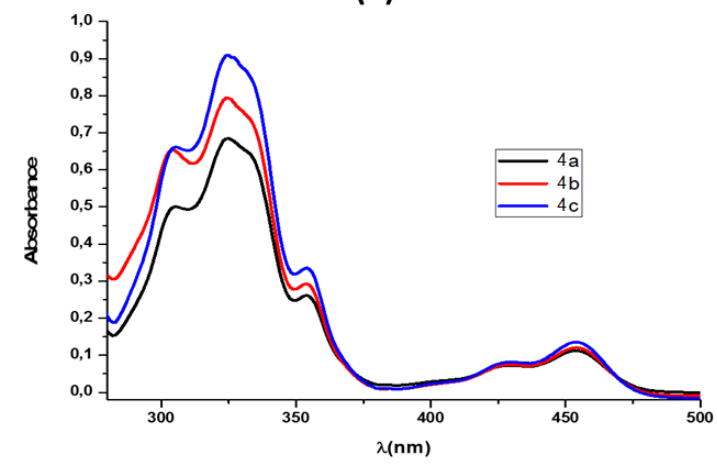

Figure 2. UV-Vis spectra of photocyclized salts $4 \mathbf{a}-\mathbf{c}(\mathbf{a})$ in chloroform $\left(\mathrm{ca} .8 \times 10^{-4} \mathrm{M}\right)$ and $(\mathbf{b})$ in methanol $\left(\mathrm{ca} .8 \times 10^{-4} \mathrm{M}\right)$.

Unlike salts 3 , the rigid polycyclic scaffold of $\mathbf{4 a - c}$ prevented non-radiative decay processes of their excited species, leading to an emission band around $480 \mathrm{~nm}$ (Figure 3).
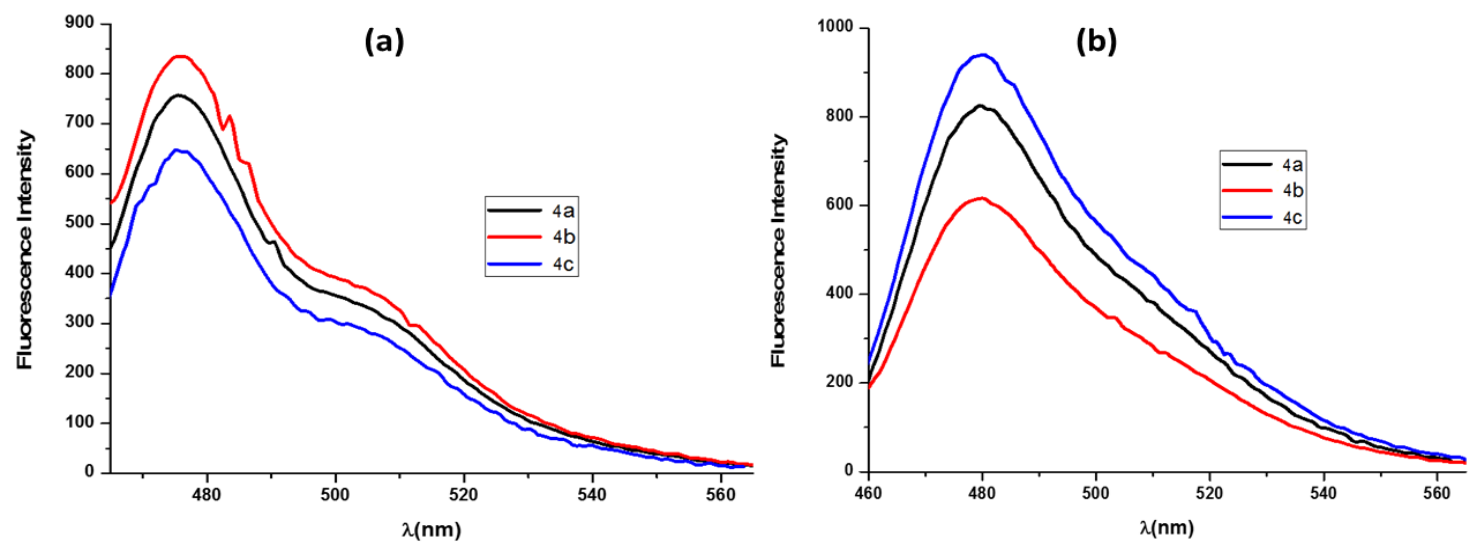

Figure 3. Fluorescence spectra of photocyclized salts $4 \mathrm{a}-\mathrm{c}(\mathrm{a})$ in chloroform $\left(c a .6 \times 10^{-6} \mathrm{M}\right)$, upon excitation at $\lambda_{\max }{ }^{\mathrm{exc}}=350 \mathrm{~nm}$; (b) in methanol $\left(c a .8 \times 10^{-6} \mathrm{M}\right)$, upon excitation at $\lambda_{\max }{ }^{\text {exc }}=350 \mathrm{~nm}$. 
The comparison of the UV-Vis and fluorescence spectra of $4 \mathbf{a}-\mathbf{c}$ in chloroform and in methanol (Figures 2 and 3) revealed some differences, but are not conclusive as to the possible formation of aggregates in the more hydrophilic methanolic medium. Discotic aggregation in methanol has been suggested for polycyclic systems analogous to 4 on the basis of dynamic light-scattering measurements [51]. Following this view of a postulated face-to-face aggregation in the solid phase of analogous highly planar hydrophobic structures [48], we cannot discard the formation of salt 4 aggregates in methanol. A more detailed investigation of this possibility, and of its consequences on the absorption spectra of these compounds and on their electron-deficiency was carried out with theoretical tools in Sections 3.4 and 3.5.

\subsection{Electrochemical Studies}

Cyclic voltammetric studies of pyridinium salts 3 and of their cyclized derivatives 4 were carried out to gain information on the potentials of these compounds as electrondeficient materials, and on the effect of the bicyclization of 3 on these potentials.

The nature of the alkyl substituent $R$ in series $3 \mathbf{a}-\mathbf{c}$ and $\mathbf{4 a - c}$, did not alter the obtained voltammograms. Figure 4 presents the cyclic voltammogram of pyridinium tetrafluoroborate 3a. The same experimental conditions were applied in obtaining the voltametric profile of the bicyclized derivative 4a shown in Figure 5.

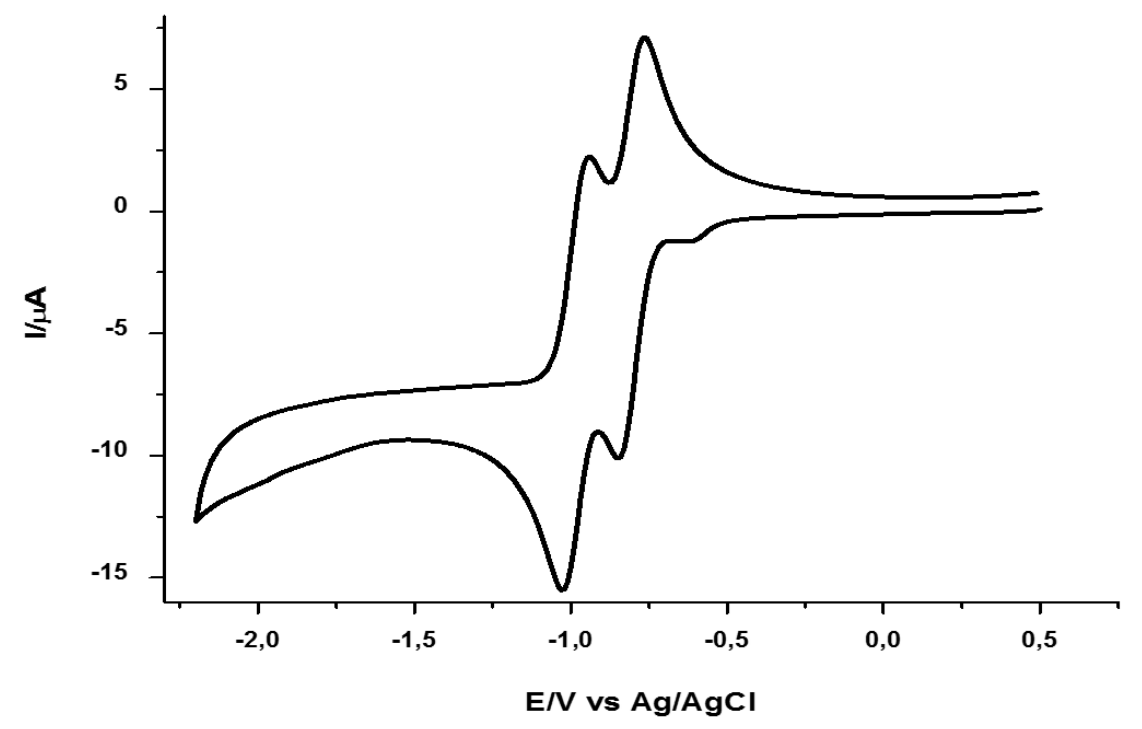

Figure 4. Cyclic voltammogram of pyridinium salt 3a $(1 \mathrm{mM})$ in DMF, with $0.1 \mathrm{M}$ TBPA as a supporting electrolyte and a scan rate of $100 \mathrm{mV} / \mathrm{s}$.

The potential of the first reduction process can be related to the electron affinity (EA) of the compounds. For this, it is necessary to relate the electrochemical potential to the vacuum level. Using Equation (1), it is possible to obtain the reduction potential $\left(\mathrm{E}_{\mathrm{red}}\right)$ relative to the vacuum level $\left(\mathrm{E}_{\mathrm{vac}}\right)$, the onset reduction potential $\left(\mathrm{E}_{\text {red }}^{\prime}\right)$, and the $\mathrm{Ag} / \mathrm{AgCl}$ reference electrode $\left(\mathrm{E}_{\mathrm{Ag} / \mathrm{AgCl}}\right)[61,62]$.

$$
\mathrm{E}_{\mathrm{red}}=\mathrm{E}_{\mathrm{red}}^{\prime}+\mathrm{E}_{\mathrm{Ag} / \mathrm{AgCl}} \approx\left(\mathrm{E}_{\text {red }}^{\prime}+\mathrm{E}_{\mathrm{vac}}+4.4\right) \mathrm{eV}
$$

which, by making $\mathrm{E}_{\mathrm{vac}}=0$, reduces to

$$
\mathrm{EA}=-\left(\mathrm{E}_{\text {red }}^{\prime}+4.4\right) \mathrm{eV}
$$




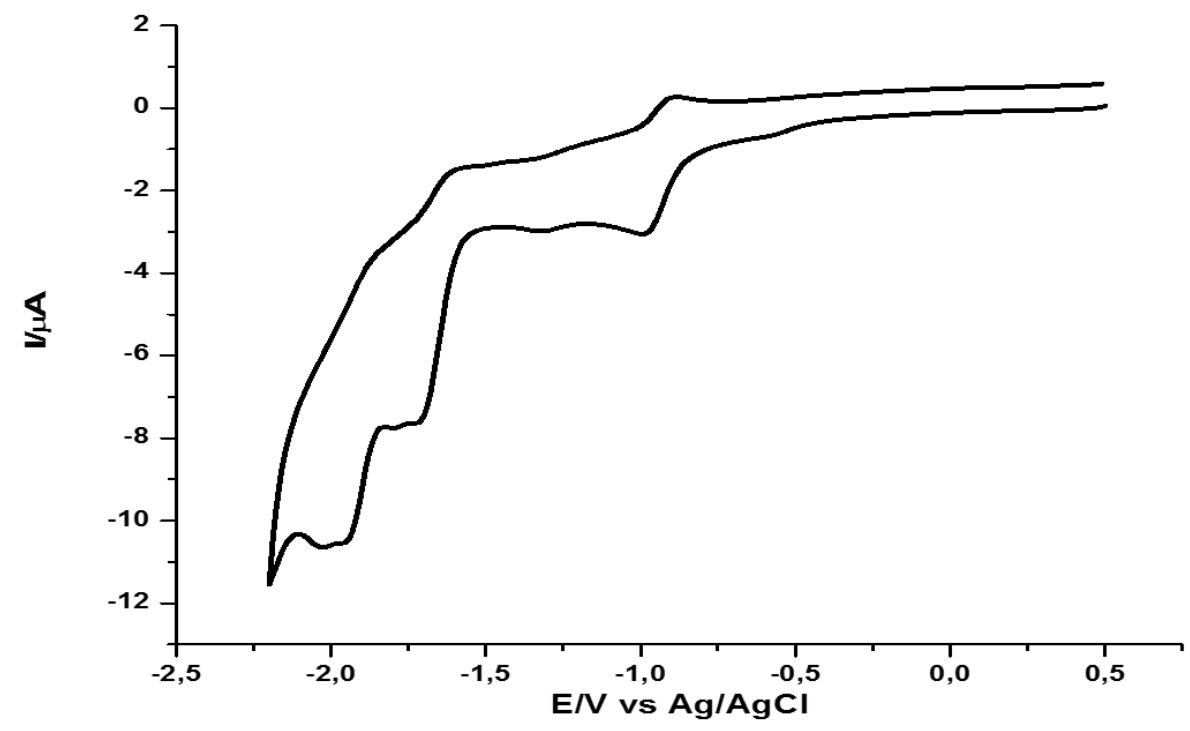

Figure 5. Cyclic voltammogram of the BPDTQ tetrafluoroborate 4 a $(1 \mathrm{mM})$ in DMF, with $0.1 \mathrm{M}$ TBPA as the supporting electrolyte and a scan rate of $10 \mathrm{~V} / \mathrm{s}$.

The obtained values of $\mathrm{E}_{\text {red }}^{\prime}$ for $4 \mathbf{a}, 4 \mathbf{b}$, and $4 \mathbf{c}$ were $-0.80,-0.78$, and $-0.77 \mathrm{~V}$.

Since no oxidation processes were observed, the HOMO energy level value can be calculated considering the optical band gap $\left(E_{g}\right)$ determined previously for each compound.

Table 2 lists the estimated values of the onset reduction potential ( $\mathrm{E}_{\text {red }}$ ), and of the HOMO and LUMO energies of BPDTQ tetrafluoroborates $4 \mathbf{a}, \mathbf{4 b}$, and $\mathbf{4 c}$.

Table 2. Onset reduction potential ( $\mathrm{E}_{\text {red }}^{\prime}$ ), LUMO energies, and HOMO data obtained.

\begin{tabular}{cccc}
\hline Compound & E' red (V) vs. Ag/AgCl $^{\prime}$ & LUMO (eV) & HOMO (eV) \\
\hline 4a & -0.80 & -3.60 & -6.20 \\
4b & -0.78 & -3.62 & -6.22 \\
$4 \mathbf{c}$ & -0.77 & -3.63 & -6.23 \\
\hline
\end{tabular}

For the sake of comparison, we list in Table 3 the HOMO and LUMO energy levels for a number of small molecules used as n-type organic semiconductors [9-13,63-66], most of them employed in organic solar cells.

Table 3. HOMO and LUMO energy values of various n-type organic semiconductors estimated under similar conditions [9-13,63-66].

\begin{tabular}{ccc}
\hline Cpd. & LUMO Energy (eV) & HOMO Energy (eV) \\
\hline T(m-BODIPY) 2 [63] & -3.49 & -5.53 \\
Cz-BAR [65] & -3.51 & -5.63 \\
Flu-BAR [65] & -3.53 & -5.81 \\
PDI-3 [10] & -3.63 & -5.75 \\
PDI-1 [10] & -3.67 & -5.79 \\
PCBM [66] & -3.83 & -5.55 \\
oo-PDI [9] & -3.90 & -6.15 \\
PDI [9] & -3.92 & -6.21 \\
Fullerene [66] & -3.92 & -5.71 \\
NDITz1 [11] & -3.99 & -6.37 \\
C8-NDTI [13] & -4.00 & -6.10 \\
bo-PDI [9] & -4.02 & -6.23 \\
IDTO-5Br [64] & -4.12 & -6.33 \\
NDINI [12] & -4.20 & -6.68 \\
\hline
\end{tabular}


Note that the HOMO energies of BPDTQ salts 4 fall within the range of corresponding values for $n$-type organic semiconductors, -6.68 (NDINI) $<-6.37$ (NDITz1) $<-6.33$ $($ IDTO-5Br) $<-6.23(4 \mathrm{c})<-6.22(4 \mathbf{b})<-6.21$ (PDI) $<-6.20(4 \mathbf{a})<-6.15$ (oo-PDI) $<-6.10$ (C8-NDTI). The same takes place with the LUMO energies, with values for the BPDTQ salts close to $-3.60 \mathrm{eV}$ (Table 2), which fall within the range of -3.49 to $-4.20 \mathrm{eV}$, observed for the organic molecules in Table 3.

In order to produce a good ohmic contact between an n-type semiconductor and a cathode, and a favorable electron injection into the former, the difference between its LUMO and the cathode work function must be ideally smaller than $0.3 \mathrm{eV}$ [67]. The estimated LUMO energies of the tetrafluoroborate salts $4 \mathbf{a}-\mathbf{c}(\approx-3.6 \mathrm{eV})$, though slightly less negative than those of the other n-type organic semiconductors of Table 3, fulfils this requirement for commonly used electrodes such as $\mathrm{Mg}$, with a work function of $-3.66 \mathrm{eV}$.

\subsection{Thermogravimetric Measurements}

The stability of BPDTQ tetrafluoroborates $4 \mathbf{a}-\mathbf{c}$ was next evaluated by thermogravimetric analysis. Figure 6 reproduces the TGA of compound $4 \mathbf{c}$, showing the loss in mass of the salt with the increased temperature. As can be seen, the BPDTQ salts were thermally very stable, only starting to decompose and lose mass at temperatures around $350{ }^{\circ} \mathrm{C}$, thus ensuring their use in solar cells.

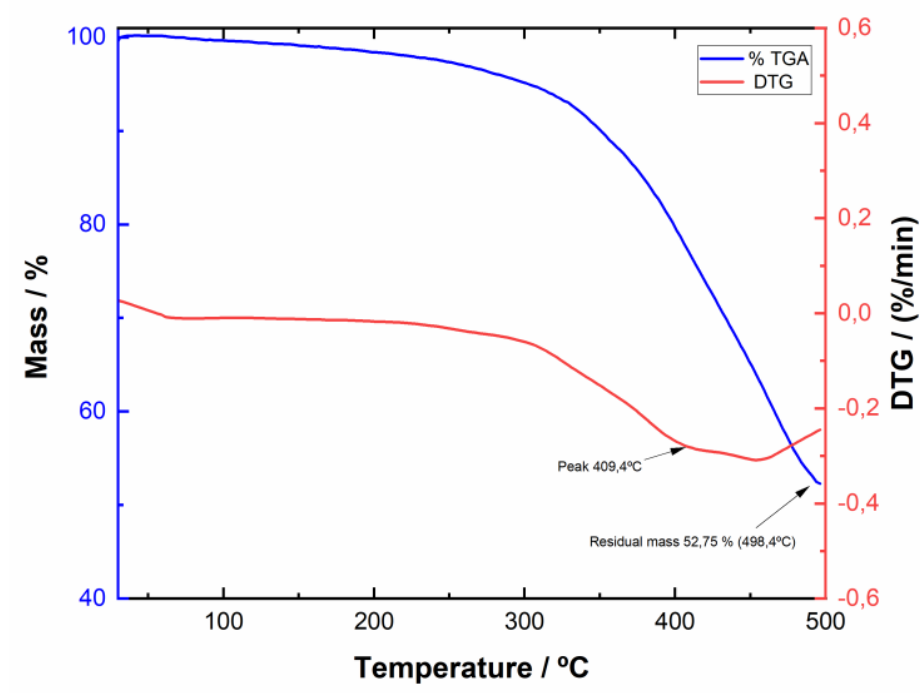

Figure 6. Thermogravimetric analysis of BPDTQ tetrafluoroborate 4c.

\subsection{Theoretical Studies}

In the previous sections, the potential of the photocyclized BPDTQ salts as promising organic n-type semiconductors was established by experimental estimates of their HOMO and LUMO energies, which fell within the range of frontier-orbital energies of other organic n-type semiconductors and led to an adequate ohmic contact between them and a metal cathode.

In order to gain a deeper insight into their behavior, we carried out theoretical calculations with three main purposes: (1) to have a clearer picture of the frontier orbitals and of the $\mathrm{HOMO} \rightarrow$ LUMO transition of the isolated cations $\mathrm{BPDTQ}^{+} ;(2)$ to investigate the effect of $\pi$-stacking of these extended planar structures on their properties as n-type electronaccepting species; and (3) to have an insight into the electron-injection process from the $\mathrm{BPTDQ}^{+}$cation into a metallic surface and to evaluate charge mobility in these species.

\subsubsection{Monomeric BPDTQ ${ }^{+}$Cations}

Frontier-orbital calculations of the optimized structures of $\mathrm{BPDTQ}^{+}$cations of $4 \mathrm{a}-\mathrm{c}$ were carried out with the hybrid DFT-B3LYP and M062X functionals, employing the 6-31G (d) basis set. Transition energies were obtained with TD-DFT calculations. Solvent effects 
were simulated with the PCM approach. Figure 7 reproduces the HOMO and LUMO of the 4 a cation. More detailed results from the frontier molecular orbital analyses are given in the Supplementary Materials.
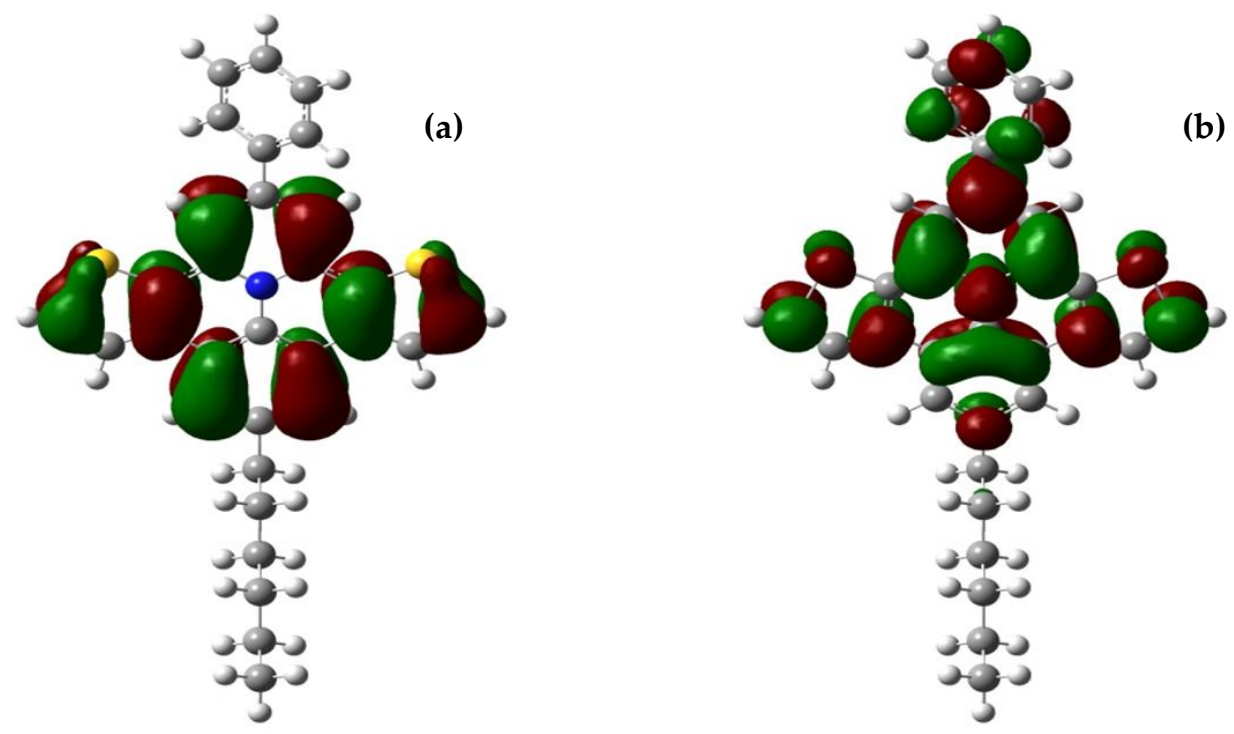

Figure 7. HOMO (a) and LUMO (b) densities of the 4a cation in methanol, calculated using the B3LYP/6-31G(d) method and the PCM option.

The HOMO-LUMO transition involves a charge-transfer process from the benzo- and diethieno-rings to the quinolizinium and the 2-phenyl substituent.

Table 4 lists some calculated values for the $4 \mathbf{a}-\mathbf{c}$ cations, which can be compared to the experimentally-derived values of Tables 4 and 5. In general, the nature of the appended alkyl chain did not affect the calculated values, so only the results for the 7-tetradecyl $\mathrm{BPDTQ}^{+}$cation are given in Table 4 .

Table 4. Calculated values of frontier-orbital energies and corresponding absorption of the longestwavelength band of the 7-tetradecyl $\mathrm{BPDTQ}^{+}$cation in methanol, together with its ionization potential IP and electron affinity EA.

\begin{tabular}{ccccccc}
\hline $\begin{array}{c}\text { DFT } \\
\text { Functional }\end{array}$ & $\begin{array}{c}\text { HOMO } \\
\text { Energy } \\
\mathbf{( e V )}\end{array}$ & $\begin{array}{c}\text { LUMO } \\
\text { Energy } \\
\mathbf{( e V )}\end{array}$ & $\begin{array}{c}\text { HOMO-LUMO } \\
\text { Energy Gap } \\
\mathbf{( e V )}\end{array}$ & $\begin{array}{c}\lambda_{\max } \text { of } \\
\text { Longest- } \\
\text { Wavelength } \\
\text { Band (nm) }\end{array}$ & $\begin{array}{c}\text { Ionization } \\
\text { Potential } \\
\text { IP (eV) }\end{array}$ & $\begin{array}{c}\text { Electron } \\
\text { Affinity } \\
\text { EA (eV) }\end{array}$ \\
\hline B3LYP & -8.84 & -5.33 & 3.51 & 426 & 9.76 & 4.11 \\
M062X & -10.04 & -4.61 & 5.43 & 381 & - & - \\
\hline
\end{tabular}

A comparison of these values with those of Tables 4 and 5 revealed a significant departure of theory from the experimentally-derived values. Calculations with the B3LYP/6$31 \mathrm{~g}(\mathrm{~d})$ method led to better results than with the DFT/M062X method, but still only tolerably reproduced the experimental values. LUMO levels in particular, were significantly lower than the experimental value of $\approx-3.6 \mathrm{eV}$. As pointed out at the end of Section 3.3, caution is required when employing a HOMO-LUMO terminology based on different methods of calculation [68]. Calculated values of HOMO and LUMO energy levels may therefore differ from those estimated by optical or electrochemical measurements. By adopting a different method of calculation, with the assumption that the LUMO energy $E_{\text {LUMO }}=-$ EA [69], the calculated LUMO energy of cation 4c draws closer to the electrochemically-derived experimental value of $-3.6 \mathrm{eV}$. 
Table 5. Calculated properties of $\pi$-stacked dimers of $4 \mathbf{a}-\mathbf{c}$ cations.

\begin{tabular}{|c|c|c|c|c|}
\hline Dimers $^{a}$ & $\begin{array}{l}\text { Distance between } \\
\pi \text {-Stacked Planes } \\
\text { (̊̊) } b\end{array}$ & $\begin{array}{l}\text { Dipole } \\
\text { Moment } \\
\text { (D) }{ }^{b}\end{array}$ & 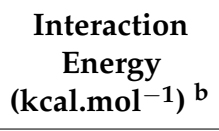 & $\begin{array}{c}\text { Longest-Wavelength } \\
\lambda_{\max } \text { Value } \\
(\mathrm{nm})^{c}\end{array}$ \\
\hline $4 a-F F$ & 3.29 & 7.49 & 14.38 & 430 \\
\hline 4a-FT & 3.31 & 0.11 & 15.51 & 432 \\
\hline $4 b-F F$ & 3.24 & 20.90 & 11.74 & 430 \\
\hline $4 \mathrm{~b}-\mathrm{FT}$ & 3.32 & 2.24 & 15.00 & 433 \\
\hline $4 c-F F$ & 3.24 & 36.41 & 8.38 & 430 \\
\hline $4 c-F T$ & 3.33 & 1.74 & 14.76 & 433 \\
\hline
\end{tabular}

\subsection{2. $\pi$-Stacking in Dimeric BPDTQ ${ }^{+}$Cations}

Although the spectra of Figures 2 and 3 did not offer sufficient evidence for the formation of aggregates in more polar methanol, reports of $\pi$-stacking in dimeric $\mathrm{PQP}^{+}[48,51]$ and in $\mathrm{BPDTQ}^{+}$cations [50] led us to investigate the possible structures and electronic properties of the dimers of the $4 \mathbf{a}-\mathbf{c}$ cations.

In the absence of data from crystal packing, we considered two forms of parallel stacking, one in which the two delocalized ring systems were aligned in the same direction (a face-to-face (FF) alignment) and another where they were aligned in opposite directions (face-to-tail (FT) alignment). The two conformations are reproduced in Figure 8 for the hexyl derivative $\mathbf{4 a}$.

Face-to-face (FF) alignment

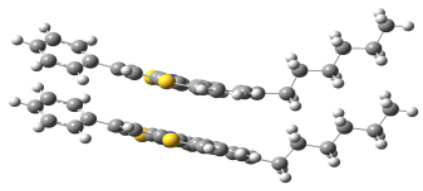

Face-to-tail (FT) alignment

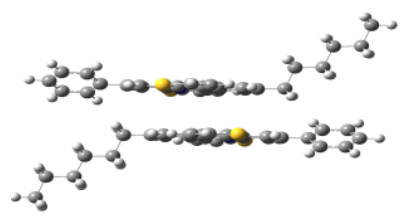

Figure 8. Face-to-face (FF) and face-to-tail (FT) alignments of dimers from cations of BPTDQ salt $4 \mathbf{a}$.

Table 5 lists some calculated properties of these dimers: the distance between their $\pi$ stacked planes, their dipole moments, the interaction energies between the two monomers, and their longest-wavelength $\lambda_{\max }$ values.

A non-covalent interaction (NCI) analysis was performed for all dimers of Table 5, and the results are summarized in Figure 9. More detailed results from the NCI analyses are given in the Supplementary Materials.

As can be seen, interactions are governed by $\pi-\pi$ charge repulsions between the two cationic monomers, shown in red, which are compensated by a large, green iso-surface of attractive van-der-Waals interactions between the two polycyclic systems [70].

Interestingly, face-to-face dimers present an additional non-covalent interaction between the parallel alkyl chains, giving rise to an additional attraction between the two monomers. Such quasi-covalent interactions between parallel chains have been described previously [71]. This "fastener effect" between alkyl chains in solid samples should be responsible for an increased conductivity and electron mobility in their resulting films. More detailed NCI analyses are shown the in Supplementary Materials (Figure S10).

The dipole moments listed in Table 5 point to significant differences between the FF and the FT conformations, giving rise to correspondingly distinct interaction energies. Relatively non-polar FT dimers should be favored in non-polar media, whereas an FF alignment should predominate in polar solvents, giving rise to J-aggregates. In the latter media, the non-covalent attraction between the alkyl chains should provide an additional stabilization to these conformers. 


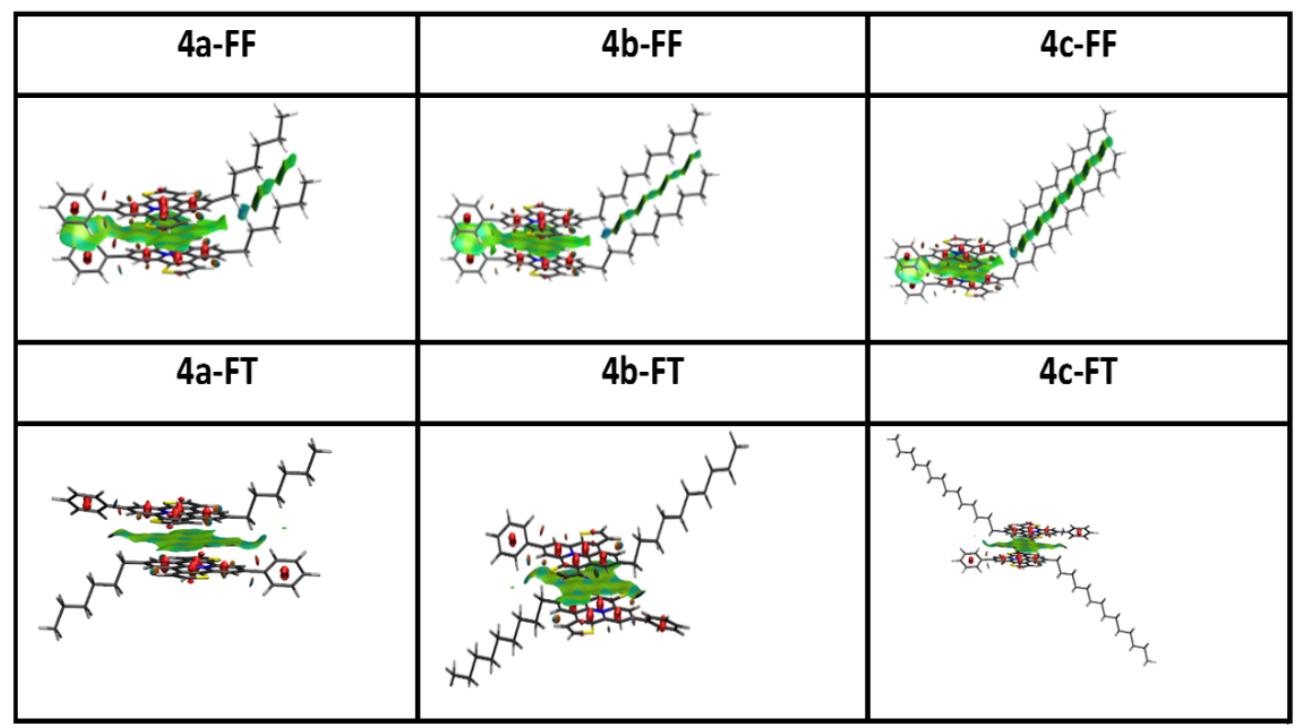

Figure 9. Face-to-face (FF) and face-to-tail (FT) $\pi$-stacked dimers of cations from $4 \mathbf{a}-\mathbf{c}$, with noncovalent interactions obtained from NCI analyses.

A noteworthy result from Table 5 is the bathochromic shift of the longest-wavelength $\lambda_{\max }$ value of the dimers when compared with the corresponding values in Table 4 for the monomeric cations. Though small $(<10 \mathrm{~nm})$, using the B3LYP functional, this red shift points to a HOMO-LUMO gap for the discotic $\pi$-stacked aggregates of compounds $4 \mathbf{a}-\mathbf{c}$ smaller than the ones listed in Table 4 for the monomeric cations. Following previous suggestions of the formation of columnar aggregates in the solid phase [48] for analogous systems, leading to materials with different discotic stackings [51,52], our calculations point to a similar possibility for polycyclic systems $\mathbf{4 a - c}$, suggesting their use as n-type semiconductors in supramolecular assemblies.

\subsubsection{Charge Mobility in Dimeric BPDTQ ${ }^{+}$Cations}

Charge mobility is an important factor to be considered in organic semiconductors. Transport properties are commonly discussed with the aid of Marcus theory [55], though other approaches are also found in the literature [72-78].

Having assumed the two parallel alignments for our cationic dimers, we estimated the charge transport in these discotic systems employing the Marcus theory $[55,79,80]$ and Einstein's equation for a one-dimensional diffusion process [81,82].

According to the latter, the diffusion $\mu$ of a charge or a hole between two parallel surfaces separated by a distance 1 is given by Equation (4)

$$
\mu=\frac{e D}{k_{B} T}=\frac{e^{2}}{k_{B} T} k_{E T}
$$

where e is the electron charge; $\mathrm{k}_{\mathrm{B}}$ is the Boltzmann's constant; and $\mathrm{k}_{\mathrm{ET}}$ is the charge-transfer rate constant between the two contiguous molecules. The $\mathrm{k}_{\mathrm{ET}}$ value can be obtained from Equation (5), derived from Marcus theory

$$
\mathrm{k}_{\mathrm{ET}}=\frac{4 \pi^{2}}{\mathrm{~h}} \frac{1}{\sqrt{4 \pi \lambda \mathrm{k}_{\mathrm{B}} \mathrm{T}}} \mathrm{t}^{2} \exp \left[\frac{-\lambda}{4 \mathrm{k}_{\mathrm{B}} \mathrm{T}}\right]
$$

where $t$ is the electronic coupling between the two contiguous molecules and $\lambda$ is the reorganization energy of the system. The first term $t$ depends on the distance between the parallel monomers and can be calculated using different methodologies [83]. In the present work, we employed Koopman's methodology using the HOMO and LUMO energies of the interacting monomers [84-86], and the hopping process where a dimeric system of two 
molecules $\mathrm{M}$ exchange hole/electrons through a hole/electron-transfer reaction, as shown below in Scheme 2:

$$
\begin{aligned}
& M+M^{+} \rightarrow M^{+}+M \\
& M+M^{-} \rightarrow M^{-}+M
\end{aligned}
$$

Scheme 2. Hole/electron exchange between two molecules $\mathrm{M}$ in a hopping process.

The reorganization energy $\lambda$ of Equation (5) comprises an inner and an outer contribution. The first arises from rapid changes in the molecular geometries of the donor (D) and acceptor (A) species, and the latter from nuclear polarization/relaxation of the surrounding medium upon an electron transfer. In our case, this outer contribution can be neglected because our system is a static crystal pack [87]. Thus, the reorganization energy $\lambda$ (inner) can be obtained from Equations (6), (7), and (10) for holes, and Equations (8)-(10) for electrons, where $E(M)$ is the total energy of species $M$ and the superscripts $A$ and $D$ refer to the electron-accepting and -donor molecules.

$$
\begin{gathered}
\lambda^{\mathrm{A}}=\mathrm{E}\left(\mathrm{M}^{+}\right)-\mathrm{E}(\mathrm{M}) \\
\lambda^{\mathrm{D}}=\mathrm{E}(\mathrm{M})-\mathrm{E}\left(\mathrm{M}^{+}\right) \\
\lambda^{\mathrm{A}}=\mathrm{E}\left(\mathrm{M}^{-}\right)-\mathrm{E}(\mathrm{M}) \\
\lambda^{\mathrm{D}}=\mathrm{E}(\mathrm{M})-\mathrm{E}\left(\mathrm{M}^{-}\right) \\
\lambda=\lambda^{\mathrm{A}}+\lambda^{\mathrm{D}}
\end{gathered}
$$

\begin{tabular}{|c|c|c|c|c|c|c|c|c|}
\hline \multirow[b]{2}{*}{ Dimer } & \multicolumn{4}{|c|}{ Electrons $^{a}$} & \multicolumn{4}{|c|}{ Holes $^{a}$} \\
\hline & $\begin{array}{l}10^{2} t_{e} \\
(e V)\end{array}$ & $\begin{array}{l}10 \lambda_{\mathrm{e}} \\
(\mathrm{eV})\end{array}$ & $\begin{array}{c}10^{-12} \mathrm{k}_{\mathrm{ET}} \mathrm{e} \\
\left(\mathrm{s}^{-1}\right)\end{array}$ & $\begin{array}{c}\mu_{\mathrm{e}} \\
\left(\mathrm{cm}^{2} \cdot \mathrm{V}^{-1} \cdot \mathrm{s}^{-1}\right)\end{array}$ & $\begin{array}{l}10^{2} t_{h} \\
(e V)\end{array}$ & $\begin{array}{c}10 \lambda_{h} \\
(\mathrm{eV})\end{array}$ & $\begin{array}{c}10^{-12} k_{E T}^{h} \\
\left(s^{-1}\right)\end{array}$ & $\begin{array}{c}\mu_{h} \\
\left(\mathrm{~cm}^{2} \cdot V^{-1} \cdot \mathrm{s}^{-1}\right)\end{array}$ \\
\hline $4 a-F F$ & 3.36 & 1.9 & 7.10 & 0.30 & 2.14 & 1.95 & 2.69 & 0.115 \\
\hline 4a-FT & 3.80 & 1.9 & 9.05 & 0.38 & 16.4 & 1.96 & 158 & 6.65 \\
\hline $4 b-F F$ & 5.17 & 2.0 & 14.7 & 0.63 & 2.56 & 2.0 & 3.46 & 0.148 \\
\hline $4 b-F T$ & 4.87 & 2.0 & 13.0 & 0.53 & 9.28 & 2.0 & 45.5 & 1.86 \\
\hline $4 c-F F$ & 2.67 & 1.95 & 4.19 & 0.18 & 10.20 & 7.9 & 0.089 & $3.84 \times 10^{-3}$ \\
\hline $4 c-F T$ & 4.25 & 1.95 & 10.6 & 0.43 & 0.41 & 7.9 & $1.49 \times 10^{6}$ & $6.1 \times 10^{-8}$ \\
\hline
\end{tabular}

Table 6 lists the obtained values for parameters $t$ and $\lambda, \mu$, and $\mathrm{k}_{\mathrm{ET}}$, for the mobility of electrons and holes in all cationic dimers from the $\mathrm{BPDTQ}^{+}$salts.

Table 6. Calculated values of the electronic coupling $t$, the reorganization energy $\lambda$, the charge-transfer rate constant $\mathrm{k}_{\mathrm{ET}}$, and the relative mobility $\mu$ for all cationic dimers from $4 \mathrm{a}-\mathrm{c}$.

An inspection of Table 6 revealed differences among the three dimers of $4 \mathbf{a}-\mathbf{c}$ and between each pair of FF/FT conformations. These variations point to possible differences in the behavior of these $\pi$-stacked dimers as semiconductors.

With the exception of $4 \mathbf{c}$ dimers, the relative hole $\left(\mu_{\mathbf{h}}\right)$ and electron $\left(\mu_{\mathbf{e}}\right)$ mobilities of all dimeric species are of the same order of magnitude, with $\mu_{\mathbf{h}}<\mu_{\mathbf{e}}$ for the FF conformations, and $\mu_{\mathbf{h}}>\mu_{\mathbf{e}}$ for the FT conformations. This amounts to predicting an ambipolar, or even a $\mathrm{p}$-character for semiconductors obtained from these dimeric molecules. Dimers 4c present a distinct behavior. For both conformers FF and FT, the relative hole mobility $\mu_{\mathbf{h}}$ is much smaller than the electron mobility $\mu_{\mathbf{e}}$, anticipating for these dimeric species an n-type semiconductor behavior. Such low hole mobilities are a result of internal hole reorganization energies $\lambda_{\mathbf{h}}$ almost four times greater than those of electrons $\lambda_{\mathbf{e}}$. The fact that dimers $4 \mathbf{c}$, with the longest $C_{14}$ chain, show a strong n-type character, at variance with analogs $4 \mathbf{a}$ and $\mathbf{4 b}$ suggests that the size of the 7-substituent alkyl chain plays an important role in the charge-transport and mobility of these dimers. This echoes previous reports 
of changes in the hopping mobility of discotic alkylated hexabenzocoronenes with the increased size of the alkyl substituents [88]. Thus, trapping and recombination in these discotic materials are retarded by the increased size of the alkyl chains, a mechanism that may also operate for materials derived from $4 \mathbf{c}$.

\section{Conclusions}

Photobicyclization of $N$-aryl-2,6-dithienyl-4-phenyl pyridinium salts led to the formation of benzodithienoquinolizinium tetrafluoroborates $\left(\mathrm{BPDTQBF}_{4}\right)$ that were investigated by spectral, electrochemical, and theoretical tools as possible n-type semiconductors for solar cells.

Their UV-Vis spectra and their voltamograms in DMF allowed for the estimation of their LUMO levels and HOMO-LUMO energy gaps, which had values compatible with those of other n-type semiconductors. Their UV-Vis spectra in chloroform and in methanol as well as their fluorescence in the same solvents did not show any conclusive evidence of aggregation, as might be surmised from reports of analogous systems in the literature. Nevertheless, theoretical calculations of the monomeric cations $\mathbf{4 a -} \mathbf{c}$ and of their $\pi$-stacked dimers in two different conformations (face-to-face, FF, and face-to-tail, FT) indicated that aggregation could lead to smaller HOMO-LUMO gaps, with a beneficial impact on the behavior of these materials as n-type semiconductors. In order to substantiate this expectation and obtain a deeper view on the many aspects that govern this complex behavior, preliminary calculations on their relative charge mobilities were performed. Estimates of relative charge mobilities for the two conformations of the cationic dimers from $4 \mathbf{a}-\mathbf{c}$, based on Einstein's diffusion equation and Marcus' theory, led to inconclusive results, with the characterization of dimers from cation $4 c$, with a long $\left(C_{14}\right)$ alkyl chain appended to the polycyclic core as a probable, potentially interesting n-type semiconductor.

In conclusion, in the present communication, the preparation of a new family of alkylated benzodithienoquinolizinium salts was described. Their electronic properties, estimated from spectroscopic and electrochemical measurements in solution, coupled with theoretical calculations in the gas-phase of their monomers and dimeric species, suggest their potential use as organic n-type semiconductors. In order to confirm their potentiality, measurements in the solid phase, and with thin films are necessary, aside from calculations based on their crystal structures. We will address these necessary issues in a future work, with the most promising compound of the series.

Supplementary Materials: The following are available online at https:/ / www.mdpi.com/article/10

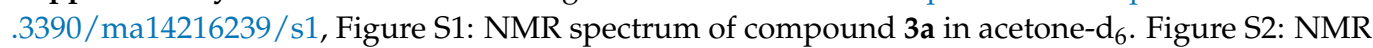
spectrum of compound $3 b$ in acetone- $\mathrm{d}_{6}$. Figure S3: NMR spectrum of compound $3 \mathbf{c}$ in acetone- $\mathrm{d}_{6}$. Figure S4: NMR spectrum of compound $4 \mathbf{a}$ in acetone- $\mathrm{d}_{6}$. Figure S5: NMR spectrum of compound $\mathbf{4 b}$ in acetone- $\mathrm{d}_{6}$. Figure S6: NMR spectrum of compound $4 \mathrm{c}$ in acetone- $\mathrm{d}_{6}$. Figure S7: Absorption spectra of pyridinium salts $\mathbf{3 a}, \mathbf{3} \mathbf{b}$, and $\mathbf{3} \mathbf{c}$ in methanol $\left(c a .9 \times 10^{-4} \mathrm{M}\right)$. Figure S8: Cyclic voltammograms obtained for tetrasubtituted pyridinium salts $3 \mathbf{b}$ and $3 \mathrm{c}$ in DMF $(\mathrm{c}=1 \mathrm{mM})$, with TBPA $0.1 \mathrm{M}$ as the supporting electrode and a scan rate of $100 \mathrm{mV} / \mathrm{s}$. Figure S9: Cyclic voltammograms obtained for BPDTQ salts $4 \mathrm{~b}$ and $4 \mathrm{c}$ in DMF ( $\mathrm{c}=1 \mathrm{mM}$ ) with TBPA $0.1 \mathrm{M}$ as the supporting electrode and a scan rate of $100 \mathrm{mV} / \mathrm{s}$. Figure S10: NCI 3D representation of isosurfaces and analysis of the $s\left(\left(\lambda_{2}\right) \rho\right)$ graph for the face-to-face (FF) and face-to-tail (FT) dimers. The color-scale code for the 3D representations is shown. Figure S11: Surfaces of HOMO (a) and LUMO (b) of the FT dimer of $4 \mathbf{a}^{+}$. Figure S12: Surfaces of HOMO (a) and LUMO (b) of the FF dimer of $4 \mathbf{a}^{+}$. Figure S13: Surfaces of HOMO (a) and LUMO (b) of $\mathbf{4} \mathbf{b}^{+}$. Figure S14: Surfaces of HOMO (a) and LUMO (b) of the FT dimer of $4 \mathbf{b}^{+}$. Figure S15: Surfaces of HOMO (a) and LUMO (b) of the FF dimer of $\mathbf{4} \mathbf{b}^{+}$. Figure S16: Surfaces of HOMO (a) and LUMO (b) of $4 c^{+}$. Figure S17: Surfaces of HOMO (a) and LUMO (b) of the FT dimer of $4 \mathrm{c}^{+}$. Figure S18: Surfaces of HOMO (a) and LUMO (b) of the FF dimer of $4 c^{+}$.

Author Contributions: Conceptualization, A.A. and M.C.R.; Methodology, A.A., K.W.-A., K.M.-B., M.G., F.C. and C.V.; Software, A.A., K.W.-A., K.M.-B. and O.V.; Validation, A.A., M.C.R. and O.V.; Formal analysis, A.A., M.C.R., K.W.-A., K.M.-B. and M.G.; Investigation, A.A., M.C.R., K.W.-A., K.M.-B., O.V., M.G., F.C. and C.V.; Resources, A.A., M.C.R., O.V., M.G., F.C. and C.V.; Data curation, 
A.A.; Writing—original draft preparation, A.A. and M.C.R.; Writing-review and editing, A.A., M.C.R., K.W.-A., K.M.-B., M.G., F.C. and C.V.; Visualization, A.A., M.C.R. and O.V.; Supervision, A.A., M.C.R. and O.V.; Project administration, A.A.; Funding acquisition, A.A. All authors have read and agreed to the published version of the manuscript.

Funding: The APC was funded by Vicerrectoría de Investigación de Universidad de Las Américas.

Institutional Review Board Statement: Not applicable.

Informed Consent Statement: Not applicable.

Data Availability Statement: Not applicable.

Acknowledgments: This work was supported by FONDECYT postdoctoral fellowship 3140573. This research was also supported by the high-performance computing system of PIDi-UTEM (SCCPIDi-UTEM CONICYT-FONDEQUIP-EQM180180). K.W. acknowledges the financial support of CONICYT/FONDECYT project \#3200270. M.G. acknowledges CONICYT/PAI/concurso nacional inserción en la academia, convocatoria 2017-79170025, and FONDECYT Project \#11180318.

Conflicts of Interest: There are no conflict to declare.

\section{References}

1. Chen, J.; Chen, Y.; Feng, L.-W.; Gu, C.; Li, G.; Su, N.; Wang, G.; Swick, S.M.; Huang, W.; Guo, X.; et al. Hole (donor) and electron (acceptor) transporting organic semiconductors for bulk-heterojunction solar cells. EnergyChem 2020, 2, 100042. [CrossRef]

2. Haddon, R.C. C 70 Thin Film Transistors. J. Am. Chem. Soc. 1996, 118, 3041-3042. [CrossRef]

3. Sugiyama, H.; Nagano, T.; Nouchi, R.; Kawasaki, N.; Ohta, Y.; Imai, K.; Tsutsui, M.; Kubozono, Y.; Fujiwara, A. Transport properties of field-effect transistors with thin films of C76 and its electronic structure. Chem. Phys. Lett. 2007, 449, 160-164. [CrossRef]

4. Shibata, K.; Kubozono, Y.; Kanbara, T.; Hosokawa, T.; Fujiwara, A.; Ito, Y.; Shinohara, H. Fabrication and characteristics of $\mathrm{C}_{84}$ fullerene field-effect transistors. Appl. Phys. Lett. 2004, 84, 2572-2574. [CrossRef]

5. Kanbara, T.; Shibata, K.; Fujiki, S.; Kubozono, Y.; Kashino, S.; Urisu, T.; Sakai, M.; Fujiwara, A.; Kumashiro, R.; Tanigaki, K. $\mathrm{N}$-channel field effect transistors with fullerene thin films and their application to a logic gate circuit. Chem. Phys. Lett. 2003, 379, 223-229. [CrossRef]

6. Kobayashi, S.; Mori, S.; Iida, S.; Ando, H.; Takenobu, T.; Taguchi, Y.; Fujiwara, A.; Taninaka, A.; Shinohara, H.; Iwasa, Y. Conductivity and Field Effect Transistor of $\mathrm{La}_{2} @ \mathrm{C}_{80}$ Metallofullerene. J. Am. Chem. Soc. 2003, 125, 8116-8117. [CrossRef] [PubMed]

7. Speller, E.M.; Clarke, A.J.; Luke, J.; Lee, H.K.H.; Durrant, J.R.; Li, N.; Wang, T.; Wong, H.C.; Kim, J.-S.; Tsoi, W.C.; et al. From fullerene acceptors to non-fullerene acceptors: Prospects and challenges in the stability of organic solar cells. J. Mater. Chem. A 2019, 7, 23361-23377. [CrossRef]

8. Kim, H.U.; Kim, J.-H.; Kang, H.; Grimsdale, A.C.; Kim, B.J.; Yoon, S.C.; Hwang, D.-H. Naphthalene-, Anthracene-, and PyreneSubstituted Fullerene Derivatives as Electron Acceptors in Polymer-based Solar Cells. ACS Appl. Mater. Interfaces 2014, 6, 20776-20785. [CrossRef]

9. Wang, H.; Chen, L.; Xiao, Y. A simple molecular structure of ortho-derived perylene diimide diploid for non-fullerene organic solar cells with efficiency over 8\%. J. Mater. Chem. A 2017, 5, 22288-22296. [CrossRef]

10. Kozma, E.; Kotowski, D.; Luzzati, S.; Catellani, M.; Bertini, F.; Famulari, A.; Raos, G. Improving the efficiency of P3HT:perylene diimide solar cells via bay-substitution with fused aromatic rings. RSC Adv. 2013, 3, 9185. [CrossRef]

11. Chen, X.; Guo, Y.; Tan, L.; Yang, G.; Li, Y.; Zhang, G.; Liu, Z.; Xu, W.; Zhang, D. Dithiazole-fused naphthalene diimides toward new n-type semiconductors. J. Mater. Chem. C 2013, 1, 1087-1092. [CrossRef]

12. Cui, X.; Xiao, C.; Zhang, L.; Li, Y.; Wang, Z. Polycyclic aromatic hydrocarbons with orthogonal tetraimides as n-type semiconductors. Chem. Commun. 2016, 52, 13209-13212. [CrossRef] [PubMed]

13. Fukutomi, Y.; Nakano, M.; Hu, J.-Y.; Osaka, I.; Takimiya, K. Naphthodithiophenediimide (NDTI): Synthesis, Structure, and Applications. J. Am. Chem. Soc. 2013, 135, 11445-11448. [CrossRef] [PubMed]

14. Lee, H.K.H.; Telford, A.M.; Röhr, J.A.; Wyatt, M.F.; Rice, B.; Wu, J.; de Castro Maciel, A.; Tuladhar, S.M.; Speller, E.; McGettrick, J.; et al. The role of fullerenes in the environmental stability of polymer:fullerene solar cells. Energy Environ. Sci. 2018, 11, 417-428. [CrossRef]

15. Heumueller, T.; Mateker, W.R.; Distler, A.; Fritze, U.F.; Cheacharoen, R.; Nguyen, W.H.; Biele, M.; Salvador, M.; von Delius, M.; Egelhaaf, H.-J.; et al. Morphological and electrical control of fullerene dimerization determines organic photovoltaic stability. Energy Environ. Sci. 2016, 9, 247-256. [CrossRef]

16. Wong, H.C.; Li, Z.; Tan, C.H.; Zhong, H.; Huang, Z.; Bronstein, H.; McCulloch, I.; Cabral, J.T.; Durrant, J.R. Morphological Stability and Performance of Polymer-Fullerene Solar Cells under Thermal Stress: The Impact of Photoinduced PC 60 BM Oligomerization. ACS Nano 2014, 8, 1297-1308. [CrossRef] [PubMed] 
17. Zhuang, T.; Wang, X.-F.; Sano, T.; Hong, Z.; Yang, Y.; Kido, J. Fullerene derivatives as electron donor for organic photovoltaic cells. Appl. Phys. Lett. 2013, 103, 203301. [CrossRef]

18. Deng, L.-L.; Xie, S.-L.; Yuan, C.; Liu, R.-F.; Feng, J.; Sun, L.-C.; Lu, X.; Xie, S.-Y.; Huang, R.-B.; Zheng, L.-S. High LUMO energy level $\mathrm{C}_{60}\left(\mathrm{OCH}_{3}\right)_{4}$ derivatives: Electronic acceptors for photovoltaic cells with higher open-circuit voltage. Sol. Energy Mater. Sol. Cells 2013, 111, 193-199. [CrossRef]

19. Katz, H.E.; Lovinger, A.J.; Johnson, J.; Kloc, C.; Siegrist, T.; Li, W.; Lin, Y.-Y.; Dodabalapur, A. A soluble and air-stable organic semiconductor with high electron mobility. Nature 2000, 404, 478-481. [CrossRef]

20. Ling, M.-M.; Erk, P.; Gomez, M.; Koenemann, M.; Locklin, J.; Bao, Z. Air-Stable n-Channel Organic Semiconductors Based on Perylene Diimide Derivatives without Strong Electron Withdrawing Groups. Adv. Mater. 2007, 19, 1123-1127. [CrossRef]

21. Babel, A.; Jenekhe, S.A. High Electron Mobility in Ladder Polymer Field-Effect Transistors. J. Am. Chem. Soc. 2003, 125, 13656-13657. [CrossRef]

22. Yan, H.; Chen, Z.; Zheng, Y.; Newman, C.; Quinn, J.R.; Dötz, F.; Kastler, M.; Facchetti, A. A high-mobility electron-transporting polymer for printed transistors. Nature 2009, 457, 679-686. [CrossRef]

23. Yin, X.; Xie, G.; Peng, Y.; Wang, B.; Chen, T.; Li, S.; Zhang, W.; Wang, L.; Yang, C. Self-Doping Cathode Interfacial Material Simultaneously Enabling High Electron Mobility and Powerful Work Function Tunability for High-Efficiency All-SolutionProcessed Polymer Light-Emitting Diodes. Adv. Funct. Mater. 2017, 27, 1700695. [CrossRef]

24. Ye, H.; Hu, X.; Jiang, Z.; Chen, D.; Liu, X.; Nie, H.; Su, S.-J.; Gong, X.; Cao, Y. Pyridinium salt-based molecules as cathode interlayers for enhanced performance in polymer solar cells. J. Mater. Chem. A 2013, 1, 3387. [CrossRef]

25. Pappenfus, T.M.; Chesterfield, R.J.; Frisbie, C.D.; Mann, K.R.; Casado, J.; Raff, J.D.; Miller, L.L. A $\pi$-Stacking Terthiophene-Based Quinodimethane Is an n-Channel Conductor in a Thin Film Transistor. J. Am. Chem. Soc. 2002, 124, 4184-4185. [CrossRef] [PubMed]

26. Chesterfield, R.J.; Newman, C.R.; Pappenfus, T.M.; Ewbank, P.C.; Haukaas, M.H.; Mann, K.R.; Miller, L.L.; Frisbie, C.D. High Electron Mobility and Ambipolar Transport in Organic Thin-Film Transistors Based on a $\pi$-Stacking Quinoidal Terthiophene. Adv. Mater. 2003, 15, 1278-1282. [CrossRef]

27. Handa, S.; Miyazaki, E.; Takimiya, K.; Kunugi, Y. Solution-Processible n-Channel Organic Field-Effect Transistors Based on Dicyanomethylene-Substituted Terthienoquinoid Derivative. J. Am. Chem. Soc. 2007, 129, 11684-11685. [CrossRef] [PubMed]

28. Kozycz, L.M.; Guo, C.; Manion, J.G.; Tilley, A.J.; Lough, A.J.; Li, Y.; Seferos, D.S. Enhanced electron mobility in crystalline thionated naphthalene diimides. J. Mater. Chem. C 2015, 3, 11505-11515. [CrossRef]

29. Tilley, A.J.; Guo, C.; Miltenburg, M.B.; Schon, T.B.; Yan, H.; Li, Y.; Seferos, D.S. Thionation Enhances the Electron Mobility of Perylene Diimide for High Performance n-Channel Organic Field Effect Transistors. Adv. Funct. Mater. 2015, 25, 3321-3329. [CrossRef]

30. Chen, W.; Zhang, J.; Long, G.; Liu, Y.; Zhang, Q. From non-detectable to decent: Replacement of oxygen with sulfur in naphthalene diimide boosts electron transport in organic thin-film transistors (OTFT). J. Mater. Chem. C 2015, 3, 8219-8224. [CrossRef]

31. Huong, V.T.T.; Nguyen, H.T.; Tai, T.B.; Nguyen, M.T. $\pi$-Conjugated Molecules Containing Naphtho[2,3-b]thiophene and Their Derivatives: Theoretical Design for Organic Semiconductors. J. Phys. Chem. C 2013, 117, 10175-10184. [CrossRef]

32. Zhao, K.; Du, J.; Wang, H.; Zhao, K.; Hu, P.; Wang, B.; Monobe, H.; Heinrich, B.; Donnio, B. Board-like Fused-Thiophene Liquid Crystals and their Benzene Analogs: Facile Synthesis, Self-Assembly, p-Type Semiconductivity, and Photoluminescence. Chem. Asian J. 2019, 14, 462-470. [CrossRef] [PubMed]

33. Li, Y.; Concellón, A.; Lin, C.-J.; Romero, N.A.; Lin, S.; Swager, T.M. Thiophene-fused polyaromatics: Synthesis, columnar liquid crystal, fluorescence and electrochemical properties. Chem. Sci. 2020, 11, 4695-4701. [CrossRef] [PubMed]

34. Ma, T.; Zhong, Y.; Wang, H.; Zhao, K.; Wang, B.; Hu, P.; Monobe, H.; Donnio, B. Butterfly-like Shape Liquid Crystals Based Fused-Thiophene as Unidimensional Ambipolar Organic Semiconductors with High Mobility. Chem. Asian J. 2021, 16, $1106-1117$. [CrossRef] [PubMed]

35. Venkateswarlu, S.; Prakoso, S.P.; Kumar, S.; Kuo, M.-Y.; Tao, Y.-T. Benzophenanthrothiophenes: Syntheses, Crystal Structures, and Properties. J. Org. Chem. 2019, 84, 10990-10998. [CrossRef]

36. Feriancová, L.; Cigáň, M.; Gmucová, K.; Kožíšek, J.; Nádaždy, V.; Putala, M. Effect of electron-withdrawing groups on molecular properties of naphthyl and anthryl bithiophenes as potential n-type semiconductors. New J. Chem. 2021, 45, 9794-9804. [CrossRef]

37. Gicevicius, M.; Bagdziunas, G.; Abduloglu, Y.; Ramanaviciene, A.; Gumusay, O.; Ak, M.; Soganci, T.; Ramanavicius, A. Experimental and Theoretical Investigations of an Electrochromic Azobenzene and 3,4-Ethylenedioxythiophene-based Electrochemically Formed Polymeric Semiconductor. ChemPhysChem 2018, 19, 2735-2740. [CrossRef]

38. Feng, X.; Marcon, V.; Pisula, W.; Hansen, M.R.; Kirkpatrick, J.; Grozema, F.; Andrienko, D.; Kremer, K.; Müllen, K. Towards high charge-carrier mobilities by rational design of the shape and periphery of discotics. Nat. Mater. 2009, 8, 421-426. [CrossRef]

39. Van de Craats, A.M.; Warman, J.M.; Fechtenkötter, A.; Brand, J.D.; Harbison, M.A.; Müllen, K. Record Charge Carrier Mobility in a Room-Temperature Discotic Liquid-Crystalline Derivative of Hexabenzocoronene. Adv. Mater. 1999, 11, 1469-1472. [CrossRef]

40. Adam, D.; Schuhmacher, P.; Simmerer, J.; Häussling, L.; Siemensmeyer, K.; Etzbachi, K.H.; Ringsdorf, H.; Haarer, D. Fast photoconduction in the highly ordered columnar phase of a discotic liquid crystal. Nature 1994, 371, 141-143. [CrossRef]

41. Pisula, W.; Feng, X.; Müllen, K. Tuning the Columnar Organization of Discotic Polycyclic Aromatic Hydrocarbons. Adv. Mater. 2010, 22, 3634-3649. [CrossRef] 
42. Yang, C.; Wu, D.; Zhao, W.; Ye, W.; Xu, Z.; Zhang, F.; Feng, X. Anion-induced self-assembly of positively charged polycyclic aromatic hydrocarbons towards nanostructures with controllable two-dimensional morphologies. CrystEngComm 2016, 18, 877-880. [CrossRef]

43. Marri, A.R.; Black, F.A.; Mallows, J.; Gibson, E.A.; Fielden, J. Pyridinium p-DSSC dyes: An old acceptor learns new tricks. Dye. Pigment. 2019, 165, 508-517. [CrossRef]

44. Sun, Z.-D.; Zhao, J.-S.; Ayyanar, K.; Ju, X.-H.; Xia, Q.-Y. Design of high performance p-type sensitizers with pyridinium derivatives as the acceptor by theoretical calculations. RSC Adv. 2020, 10, 10569-10576. [CrossRef]

45. Rafiq, M.; Jing, J.; Liang, Y.; Hu, Z.; Zhang, X.; Tang, H.; Tian, L.; Li, Y.; Huang, F. A pyridinium-pended conjugated polyelectrolyte for efficient photocatalytic hydrogen evolution and organic solar cells. Polym. Chem. 2021, 12, 1498-1506. [CrossRef]

46. Katritzky, A.R.; Zakaria, Z.; Lunt, E. The photocyclisation of 1,2-Ciarylpyridinium cations and the photobiscyclisation of 1,2,6-triarylpyridinium cations. J. Chem. Soc. Perkin Trans. 1980, 1, 1879. [CrossRef]

47. Katritzky, A.R.; Agha, B.; de Ville, G.Z.; Lunt, E.; Knyazhanskii, M.I.; Tymyanskii, Y.R.; Pyshchev, A.I. Photocyclization of 1,2-diaryl- and photobicyclization of 1,2,6-triarylpyridinium cations. Chem. Heterocycl. Compd. 1984, 20, 1245-1254. [CrossRef]

48. Wu, D.; Pisula, W.; Enkelmann, V.; Feng, X.; Müllen, K. Controllable Columnar Organization of Positively Charged Polycyclic Aromatic Hydrocarbons by Choice of Counterions. J. Am. Chem. Soc. 2009, 131, 9620-9621. [CrossRef]

49. Fortage, J.; Tuyèras, F.; Ochsenbein, P.; Puntoriero, F.; Nastasi, F.; Campagna, S.; Griveau, S.; Bedioui, F.; Ciofini, I.; Lainé, P.P. Expanded Pyridiniums: Bis-cyclization of Branched Pyridiniums into Their Fused Polycyclic and Positively Charged DerivativesAssessing the Impact of Pericondensation on Structural, Electrochemical, Electronic, and Photophysical Features. Chem. Eur. J. 2010, 16, 11047-11063. [CrossRef] [PubMed]

50. Aracena, A.; Rezende, M.C.; Encinas, M.V.; Vergara, C.; Vásquez, S.O. Aggregation phenomena in photobicyclised pyridinium salts. New J. Chem. 2017, 41, 14589-14594. [CrossRef]

51. Wu, D.; Zhi, L.; Bodwell, G.J.; Cui, G.; Tsao, N.; Müllen, K. Self-Assembly of Positively Charged Discotic PAHs: From Nanofibers to Nanotubes. Angew. Chem. Int. Ed. 2007, 46, 5417-5420. [CrossRef]

52. Wu, D.; Feng, X.; Takase, M.; Haberecht, M.C.; Müllen, K. Synthesis and self-assembly of dibenzo[jk,mn]naphtho[2,1,8fgh]thebenidinium derivates. Tetrahedron 2008, 64, 11379-11386. [CrossRef]

53. Mali, K.S.; Wu, D.; Feng, X.; Müllen, K.; Van der Auweraer, M.; De Feyter, S. Scanning Tunneling Microscopy-Induced Reversible Phase Transformation in the Two-Dimensional Crystal of a Positively Charged Discotic Polycyclic Aromatic Hydrocarbon. J. Am. Chem. Soc. 2011, 133, 5686-5688. [CrossRef]

54. Cui, K.; Ivasenko, O.; Mali, K.S.; Wu, D.; Feng, X.; Müllen, K.; De Feyter, S.; Mertens, S.F.L. Potential-driven molecular tiling of a charged polycyclic aromatic compound. Chem. Commun. 2014, 50, 10376-10378. [CrossRef]

55. García, G.; Moral, M.; Granadino-Roldán, J.M.; Garzón, A.; Navarro, A.; Fernández-Gómez, M. Theoretical Approach to the Study of Thiophene-Based Discotic Systems As Organic Semiconductors. J. Phys. Chem. C 2013, 117, 15-22. [CrossRef]

56. Bello, A.M.; Kotra, L.P. Improved synthesis of pyrylium salts leading to 2,4-disubstituted diarylfurans via novel mechanism. Tetrahedron Lett. 2003, 44, 9271-9274. [CrossRef]

57. East, G.A.; del Valle, M.A. Easy-to-Make Ag/AgCl Reference Electrode. J. Chem. Educ. 2000, 77, 97. [CrossRef]

58. Frisch, M.; Trucks, G.; Schlegel, H.; Scuseria, G.; Robb, M.; Cheeseman, J.; Scalmani, G.; Barone, V.; Mennucci, B.; Petersson, G.; et al. GAUSSIAN 09; Revision E.01; Gaussion, Inc.: Wallingford, CT, USA, 2009.

59. Contreras-García, J.; Johnson, E.R.; Keinan, S.; Chaudret, R.; Piquemal, J.-P.; Beratan, D.N.; Yang, W. NCIPLOT: A Program for Plotting Noncovalent Interaction Regions. J. Chem. Theory Comput. 2011, 7, 625-632. [CrossRef] [PubMed]

60. Costa, J.C.S.; Taveira, R.J.S.; Lima, C.F.R.A.C.; Mendes, A.; Santos, L.M.N.B.F. Optical band gaps of organic semiconductor materials. Opt. Mater. 2016, 58, 51-60. [CrossRef]

61. García, M.; Carfumán, K.; Díaz, C.; Garrido, C.; Osorio-Román, I.; Aguirre, M.J.; Isaacs, M. Multimetallic porphyrins/polyoxotungstate modified electrodes by layer-by-layer method: Electrochemical, spectroscopic and morphological characterization. Electrochim. Acta 2012, 80, 390-398. [CrossRef]

62. Crespilho, F.N.; Zucolotto, V.; Siqueira, J.R., Jr.; Carvalho, A.J.F.; Oliviera, O.N., Jr. Using Electrochemical Data to Obtain Energy Diagrams for Layer-By-Layer Films from Metallic Phthalocyanines. Int. J. Electrochem. Sci. 2006, 1, 151-159.

63. Liu, W.-X.; Yao, J.-N.; Zhan, C.-L. Tailoring the photophysical and photovoltaic properties of boron-difluorodipyrromethene dimers. Chinese Chem. Lett. 2017, 28, 875-880. [CrossRef]

64. Deng, Y.; Sun, B.; Quinn, J.; He, Y.; Ellard, J.; Guo, C.; Li, Y. Thiophene-S,S-dioxidized indophenines as high performance n-type organic semiconductors for thin film transistors. RSC Adv. 2016, 6, 45410-45418. [CrossRef]

65. Lim, E. Two A-D-A-type Non-Fullerene Small Molecule Acceptors Based on 1,3-Dimethylbarbituric Acid for OPVs. Bull. Korean Chem. Soc. 2017, 38, 285-288. [CrossRef]

66. Zhang, X.; Li, X.-D.; Ma, L.-X.; Zhang, B. Electronic and electrochemical properties as well as flowerlike supramolecular assemblies of fulleropyrrolidines bearing ester substituents with different alkyl chain lengths. RSC Adv. 2014, 4, 60342-60348. [CrossRef]

67. Bredas, J.-L. Mind the gap! Mater. Horiz. 2014, 1, 17-19. [CrossRef]

68. Zhan, C.-G.; Nichols, J.A.; Dixon, D.A. Ionization Potential, Electron Affinity, Electronegativity, Hardness, and Electron Excitation Energy: Molecular Properties from Density Functional Theory Orbital Energies. J. Phys. Chem. A 2003, 107, 4184-4195. [CrossRef]

69. Inokuchi, H.; Imaeda, K.; Enoki, T.; Mori, T.; Maruyama, Y.; Saito, G.; Okada, N.; Yamochi, H.; Seki, K.; Higuchi, Y.; et al. Tetrakis(methyltelluro)tetrathiafulvalene (TTeC1TTF), a high-mobility organic semiconductor. Nature 1987, 329, 39-40. [CrossRef] 
70. Azizi, A.; Ebrahimi, A. Theoretical investigation of the $\pi^{+}-\pi^{+}$stacking interactions in substituted pyridinium ion. J. Mol. Graph. Model. 2017, 77, 225-231. [CrossRef]

71. Saito, G.; Yoshida, Y. Development of Conductive Organic Molecular Assemblies: Organic Metals, Superconductors, and Exotic Functional Materials. Bull. Chem. Soc. Jpn. 2007, 80, 1-137. [CrossRef]

72. Bässler, H. Charge Transport in Disordered Organic Photoconductors a Monte Carlo Simulation Study. Phys. Solid. State 1993, 175, 15-56. [CrossRef]

73. Coropceanu, V.; Cornil, J.; da Silva Filho, D.A.; Olivier, Y.; Silbey, R.; Brédas, J.-L. Charge Transport in Organic Semiconductors. Chem. Rev. 2007, 107, 926-952. [CrossRef]

74. Ishii, H.; Kobayashi, N.; Hirose, K. Carrier transport calculations of organic semiconductors with static and dynamic disorder. Jpn. J. Appl. Phys. 2019, 58, 110501. [CrossRef]

75. Schweicher, G.; Garbay, G.; Jouclas, R.; Vibert, F.; Devaux, F.; Geerts, Y.H. Molecular Semiconductors for Logic Operations: Dead-End or Bright Future? Adv. Mater. 2020, 32, 1905909. [CrossRef]

76. Fratini, S.; Nikolka, M.; Salleo, A.; Schweicher, G.; Sirringhaus, H. Charge transport in high-mobility conjugated polymers and molecular semiconductors. Nat. Mater. 2020, 19, 491-502. [CrossRef]

77. Sosorev, A.Y. Simple charge transport model for efficient search of high-mobility organic semiconductor crystals. Mater. Des. 2020, 192, 108730. [CrossRef]

78. Shuai, Z.; Li, W.; Ren, J.; Jiang, Y.; Geng, H. Applying Marcus theory to describe the carrier transports in organic semiconductors: Limitations and beyond. J. Chem. Phys. 2020, 153, 080902. [CrossRef] [PubMed]

79. Murphy, A.R.; Fréchet, J.M.J. Organic Semiconducting Oligomers for Use in Thin Film Transistors. Chem. Rev. 2007, 107, 1066-1096. [CrossRef] [PubMed]

80. Dong, H.; Wang, C.; Hu, W. High performance organic semiconductors for field-effect transistors. Chem. Commun. 2010, 46, 5211. [CrossRef] [PubMed]

81. Lemaur, V.; da Silva Filho, D.A.; Coropceanu, V.; Lehmann, M.; Geerts, Y.; Piris, J.; Debije, M.G.; van de Craats, A.M.; Senthilkumar, K.; Siebbeles, L.D.A.; et al. Charge Transport Properties in Discotic Liquid Crystals: A Quantum-Chemical Insight into Structure-Property Relationships. J. Am. Chem. Soc. 2004, 126, 3271-3279. [CrossRef]

82. Pope, M.; Swenberg, C.E. Electronic Processes in Organic Crystals and Polymers, 2nd ed.; Oxford University Press: New York, NY, USA, 1999; ISBN 978-0195129632.

83. Huang, J.; Kertesz, M. Validation of intermolecular transfer integral and bandwidth calculations for organic molecular materials. J. Chem. Phys. 2005, 122, 234707. [CrossRef] [PubMed]

84. Li, X.-Y.; Tang, X.-S.; He, F.-C. Electron transfer in poly(p-phenylene) oligomers: Effect of external electric field and application of Koopmans theorem. Chem. Phys. 1999, 248, 137-146. [CrossRef]

85. Lan, Y.-K.; Huang, C.-I. A Theoretical Study of the Charge Transfer Behavior of the Highly Regioregular Poly-3-hexylthiophene in the Ordered State. J. Phys. Chem. B 2008, 112, 14857-14862. [CrossRef] [PubMed]

86. Bao, Z.; Locklin, J. Organic Field-Effect Transistors; CRC Press: Boca Raton, FL, USA, 2007.

87. McMahon, D.P.; Troisi, A. Evaluation of the External Reorganization Energy of Polyacenes. J. Phys. Chem. Lett. 2010, 1, 941-946. [CrossRef]

88. Warman, J.M.; Piris, J.; Pisula, W.; Kastler, M.; Wasserfallen, D.; Müllen, K. Charge Recombination via Intercolumnar Electron Tunneling through the Lipid-like Mantle of Discotic Hexa-alkyl-hexa- p eri -hexabenzocoronenes. J. Am. Chem. Soc. 2005, 127, 14257-14262. [CrossRef] [PubMed] 